\title{
THE FORM ANALYSIS OF "SKY" COMPOSED FOR SIX-HANDS PIANO
}

\author{
Şirin AKBULUT DEMIRCI \\ Assoc. Prof. Education Faculty, Music Education Faculty. Uludag University, Turkey \\ https://orcid.org/0000-0001-8904-4920 \\ akbulut.sirin@gmail.com \\ Berkant GENÇKAL \\ Assoc. Prof. State Conservatory, School for Music and Drama. Anadolu University, Turkey \\ https://orcid.org/0000-0001-5792-2100 \\ bgenckal@gmail.com
}

\begin{abstract}
The piano, which is a solo instrument that takes part in educational process, can take role not only in instrumental education but also in chamber music education as well with the 6-hands pieces for three players that perform same composition on a single instrument. According to the international 6-hands piano literature, although the works of Alfred Schnittke's Hommage, Carl Czerny's Op.17 and 741, Paul Robinson's Pensees and Montmartre and many more are included, the Turkish piano literature has been found to have a limited number of compositions. The aim of the work is to contribute to the field by presenting musical analysis about the place and the importance of the educational use of the works composed for 6-hands which are extremely rare in the Turkish piano literature. As an example, the piece named Sky composed by Hasan Barış Gemici is considered. Analysis is supported by comparative methods in form, structuralism, rhythm, theoretical applications and performance; it also gives information about basic playing techniques. It is thought that this study carries importance in contributing to the limited number of Turkish 6-hands piano literature and researchers who will conduct research in this regard, in terms of creating resources for performers and composers who will interpret the literature. As a result of the research the inner world's aggression and inspirations from elements like rain, thunder, heart beat that are transformed to piano, which carry symbolic meanings that are composed with tight-knit structure; besides all these mentioned before the dramatic content that is uncovered by the chords of the trumpet section of the orchestra, timpani pulsation and the dance-like movements have been reached.
\end{abstract}

Keywords: Piano education, six hands piano, Turkey, Turkish piano literature, chamber music

\section{ALTI EL PIYYANO İÇINN BESTELENEN “GÖK"ÜN BİÇIMSEL ANALIZİ}

ÖZ

Solo çalg1 olarak çalg1 eğitiminde yer alan piyano, tek piyanoda üç icracının aynı eseri yorumlamasından oluşan 6-el piyano eserleri ile sadece çalgı eğitiminde değil aynı zamanda oda müziği eğitiminde de görev üstlenebilmektedir. Uluslararası 6-el piyano literatürüne bakıldığında Alfred Schnittke'nin Hommage, Carl Czerny'nin Op.17 ve 741, Paul Robinson'un Pensees ve Montmartre gibi eserlerin yer almasına karşın Türk piyano literatürünün çok sınırlı sayıda esere sahip olduğu belirlenmiştir. Çalışmanın amacı, Türk piyano literatüründe çok nadir yer alan 6-el için bestelenmiş eserlerin eğitim amaçlı kullanımındaki yeri ve önemi hakkında müzikal analizler sunarak alana katkı sağlamaktır. Örnek olarak, Hasan Barış Gemici'nin Gök adlı parçası ele alınmaktadır. Analizler, karşılaştırmalı yöntemlerle desteklenerek biçim, yapısalcılık, ritim, teorik uygulamalar ve performans; temel çalış teknikleri hakkında bilgi verir niteliktedir. $\mathrm{Bu}$ çalışmanın, sınırlı sayıdaki Türk 6-el piyano literatürüne katkı sağlayarak bu konuda araştırma

Submit Date: 11.09.2017, Acceptance Date: 16.03.2018, DOI NO: 10.7456/10802100/014 340

Research Article - This article was checked by Turnitin

Copyright $\odot$ The Turkish Online Journal of Design, Art and Communication 
yapacak araştırmacılara, literatürü yorumlayacak icracılara ve bestecilere kaynak oluşturulması açısından önemli olduğu düşünülmektedir. Araştırmanın sonucunda iç dünyasının agresifliği ve de sık1 formal yapı ile bestelenmiş ve içinde yağmur, gök gürültüsü, kalp atış1 gibi doğadan esinlenmelerin piyanoya aktarıldığı sembolik anlamlar yüklenmiş öğelerin işlendiği; bunların yanı sıra orkestradaki trompet bölümü, timpani ve dansa benzer bölümleri dramatik içeriğini açığa çıkardığı bulgulara ulaşılmıştır.

\section{Anahtar kelimeler: Piyano eğitimi, 6-el piyano, Türkiye, Türk piyano literatürü, oda müziği}

\section{INTRODUCTION}

Many composers used piano as a solo instrument in their compositions together with chamber music and orchestral music throughout centuries. There are plenty of 4-hands works by Bach, Mozart, Beethoven, Brahms, Debussy, Moszkowski, Godard, Gregh and many more. The basic notion of this type of usage the piano relies on a division of the keyboard into two main sections in which the first pianist plays accompaniment on low register while the second one explores the melodic contour on high register. It is also used in terms of educational purpose while the first pianist is usually the teacher and the second one pupil (Beyer: 30-35, Ereren, 2009: 60, 63-65, 71, 76 and 91).

Whereas the anthology of 6-hand piano is extremely rare, because of the limited range available to each player, many of the pieces written for the combination are elementary in nature; many more are arrangements of pieces for other forces (Freischütz Overture is arranged for 6-hands piano by G. Micheuz; F. Schubert's Auf Dem Waßer Zu Singen and Erlkönig songs are arranged for 6-hands piano by Özgür Ünald1) (Rare Six Hands Piano, access date 10.01.2010). But there are small number original works and a handful of virtuoso three player groups have emerged in $21^{\text {st }}$ Century. S. Rachmaninov's Two Pieces for Six Hands: Valse and Romance; A. Schnittke's Hommage, Tomislav Baynov's Metrorhythmia 1, Dionysis Boukuvala's Fantasy on a theme by Steve Reich, Gurlitt's Six Pieces for Six Hands and etc.

It is thought to be Hasan Barış Gemici's composition Sky as the first example in Turkish 6-hands piano literature which scores and performance note has been able to reach the audience. For that reason this piece was chosen as an example that will be carefully examine in this study. Another reason to work on this topic is the limited amount of scientific investigation about 6-hands piano works. Tracing the database two works have been found in Turkey. The first one is an article entitled as The Effectiveness of Cooperative Learning Method on Teaching Six Hands Piano Piece: An Action Research (Deniz, 2015) and the second one is a conference oral presentation entitled as Six Hands Piano in Turkey (Akbulut Demirci, 2016).

The aim of this work is to provide musical analysis that will contribute with the importance of 6hands piano pieces within educational purpose and enriching the Turkish piano literature.

The analysis the work is based on comparative methods that are supported by musical form, structuralism, rhythm, theoretical applications, performance, and basic playing techniques. The main approach musical analysis is cooperated with composer himself through online meetings and face-to-face interview held on $3^{\text {rd }}$ of November 2017 (10:00-11:45 a.m.).

It is believed that this study will collaborate in the scientific world as an important resource for researchers who want to work on this field, as well as performers who wants to interpret this work and composers considering the limited amount of works done upon 6-hands piano compositions.

\section{FINDINGS}

The entire form of the piece is in Compound Ternary structure, which also resembles to a Quasi Sonata form with Exposition, Development and Recapitulation parts. It also bears two inner parts that expose the Introduction and the Bridge that is presented as Figure 1 below. 


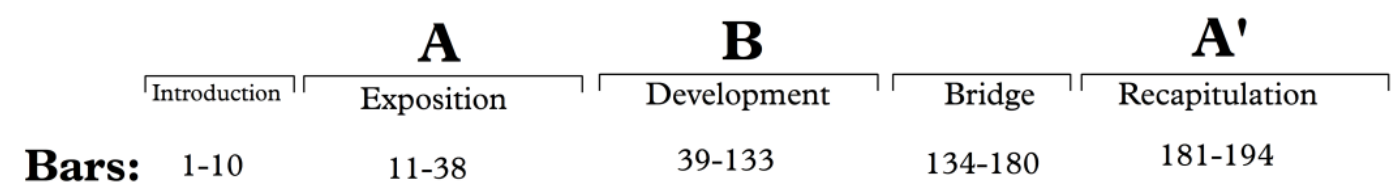

Figure 1: The Scheme of the Form of the Piece.

The Introduction part starts with a unison passage that portrays composer's signature (The same signature motive of that piece also exists in composer's second work Theme and Variations for violin and Piano. The composition is dedicated to Parkan Sanlıkol and is worked out between $14^{\text {th }}$ of September 2017. Its final revision is done in 2018). It has been consisted three main descending notes: B - B b - G, which is shown as Figure 2 below. These notes constitute the [014] set where on the second bar it turns to $\mathrm{A} b-\mathrm{A} \sharp-\mathrm{E} b$, transforming the combination into [017].

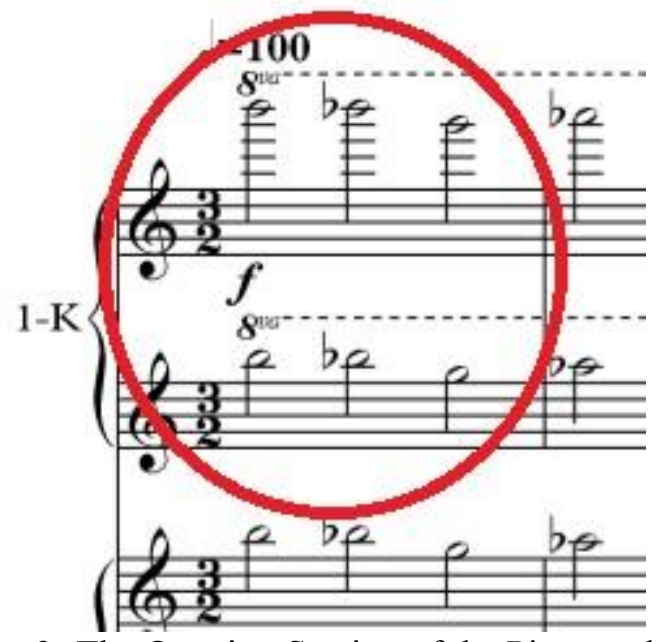

Figure 2: The Opening Section of the Piece and Composer's Signature.

The third bar is another 3-note collection of F - D b - C notes. The corresponding set to these notes is [015]. In this respect, the entire opening segment's pitch collection is as follow:

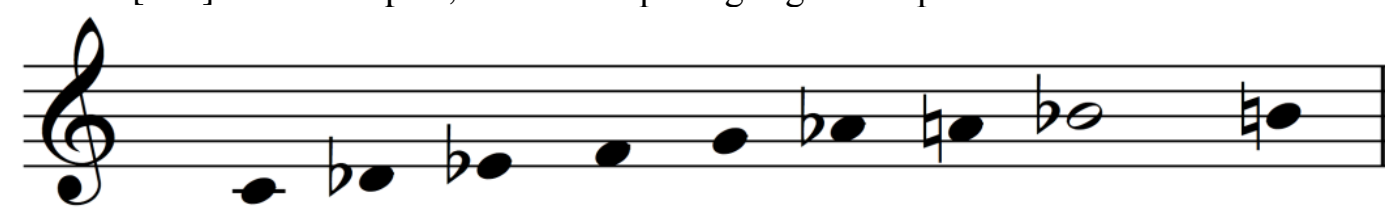

Figure 3: The Scale that Constitutes the Opening Section of the Piece.

The scale given at Figure 3 above is [01234568T] set that belongs to [9-6] category according to Joseph N. Straus's (1999) list.

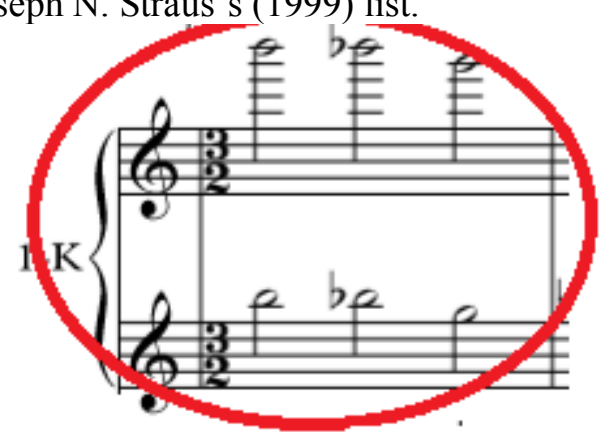

Figure 4: The Signature Motive at Bar 4.

We find the same approach at bar 4 where the signature motive is presented as expansion of the melodic progression, which is shown as Figure 4 above. 


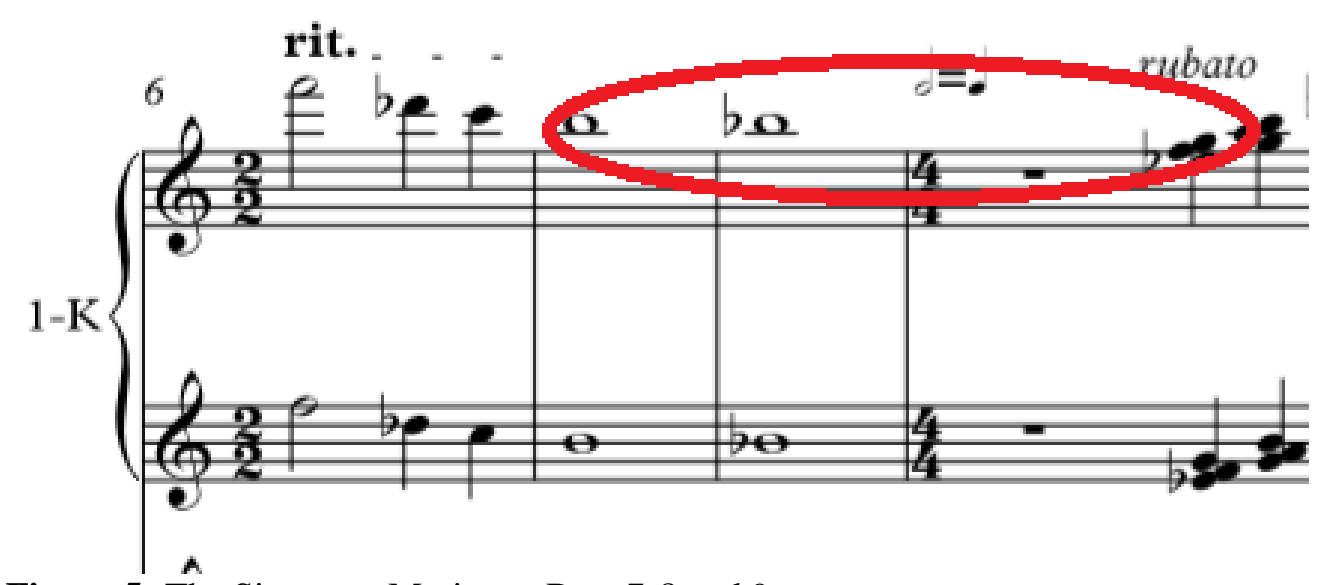

Figure 5: The Signature Motive at Bars 7-8 and 9.

The prominent repetition of B - B b-G signature motive is once again presented but now in different combination as shown in Figure 5. Figures 2, 4 and 5 are presenting the composer's signature in the opening section respectively. The opening section ends with ascending passage that bears whole-tone units.
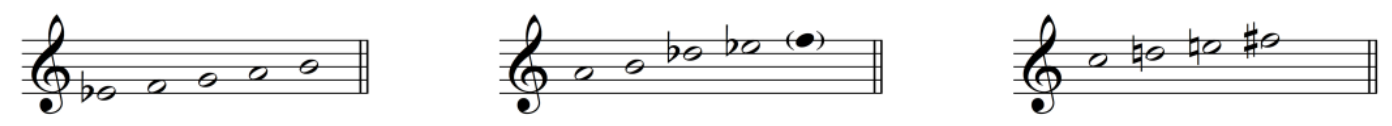

Figure 6: The Whole-Tone Segments at the End of Introduction Part.

The Exposition Part starts at bar 11 with a new fragment which according to composer it is a theme that describes distressed moments in his life.

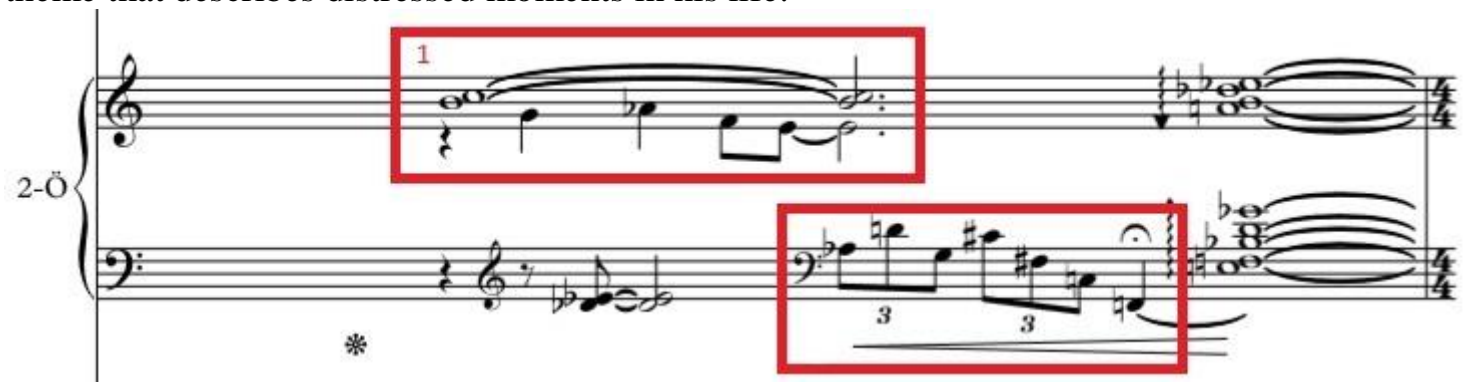

Figure 7: The Opening Theme of the Exposition Part.

The Exposition part starts with two contradicting motives: the basic idea and the contrasting idea shown as Figure 7 above. Figure 8 is summarization of the Figure 7 and according to Figure 8 there is short declamation of the second pianist that projects the entire twelve-tone collection. Examining the statement more carefully, the twelve-tone collection may have been categorized as follow:
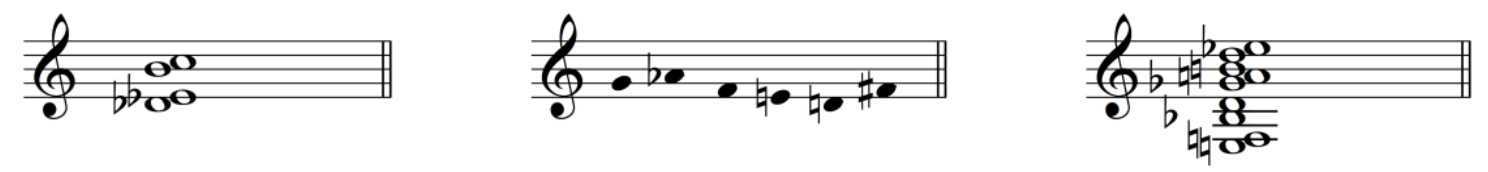

Figure 8: The Pitch-Collection of the Exposition's Opening Theme.

At bar 13, the tempo of the music slows down to $J=55$ in which the second fragment occurs. 
The Turkish Online Journal of Design, Art and Communication - TOJDAC

ISSN: 2146-5193, April 2018 Volume 8 Issue 2, p. 340-363

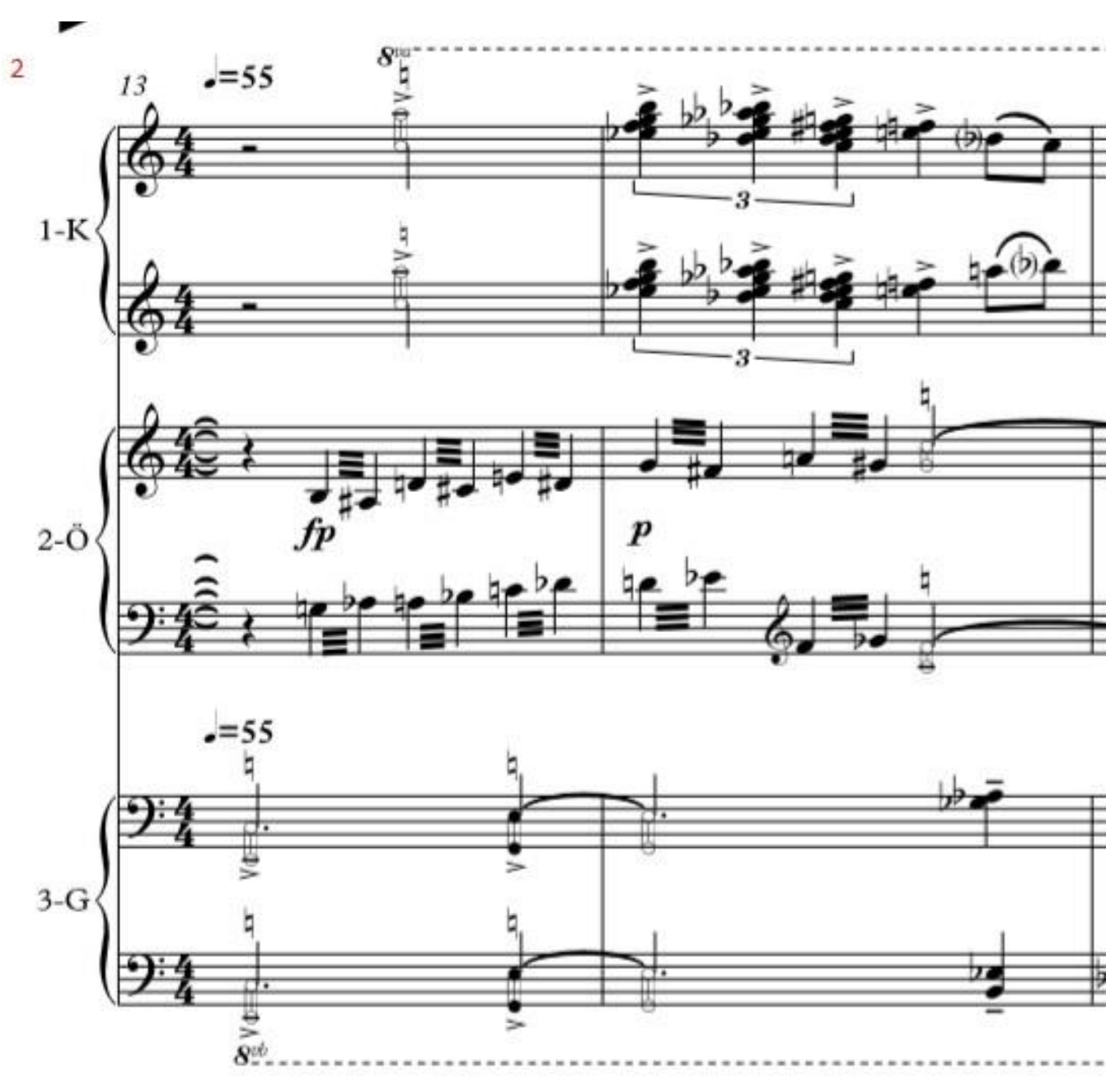

Figure 9: The Second Fragment of the Exposition Part.

We find the composer's signature at bar 14 supported with the clusters of the third pianist and ascending tremolandi of the second pianist as shown in Figure 9. At bar 15, the third pianist plays clear pulsation of the rhythmic units. According to composer, these units describe hear beats and it is shown as Figure 10 respectively.

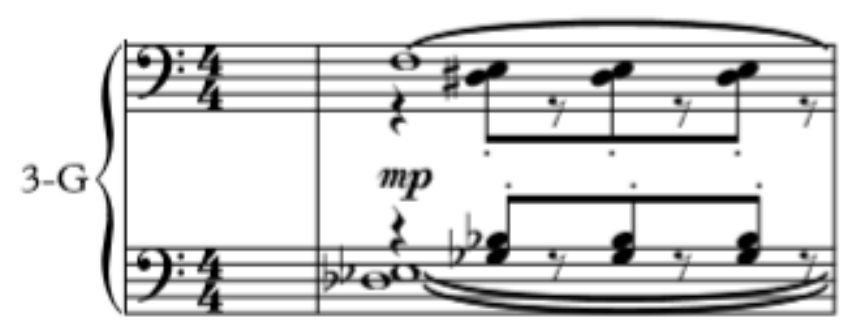

Figure 10: The Heart Beats Motive.

The prominent major second interval of the left hand $(\mathrm{D} b-\mathrm{E} b)$ is supported with another pitch (F) of the right hand creating clear major mould in which the pulsation unit contradicts this statement with ( $\mathrm{G} b-\mathrm{B} b-\mathrm{D} \#-\mathrm{E})$ pitches in a sort of "minorish" polarity.

The dotted rhythmic units of the first pianist at bar 16 resembles to the texture presented before at bar 13, but in this context the passage is not entirely ascending but sometimes descending as 
well. Here, the composer does not hesitate to put his signature once again which is presented at bars 17 and 18 of the third pianist shown as Figure 11.

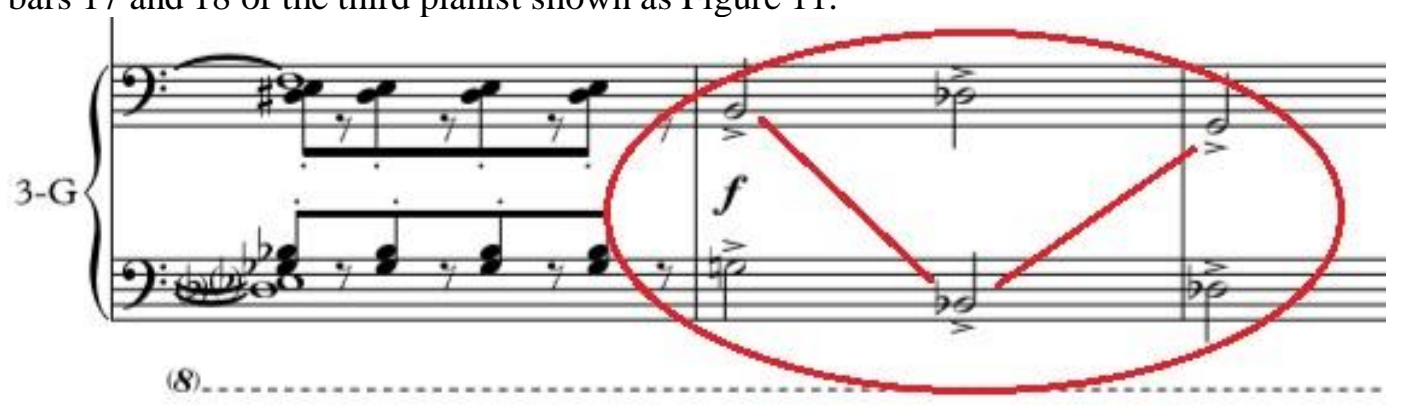

Figure 11: The Signature Motive at Bar 17 of the Third Pianist.

The fragment ends at bar 19 respectively with the descending chromatic six-tuplets and fivetuplet's rhythmical decrescendo shown as Figure 12.

Fragment 1 occurs once again at bar 21 where we find similar approach of the compositional process but the gesture here is more developed and extended in general. It is shown as Figure 13 and here we witness two particular treatments of the fragment in terms of exposing the material and its response of the second pianist.

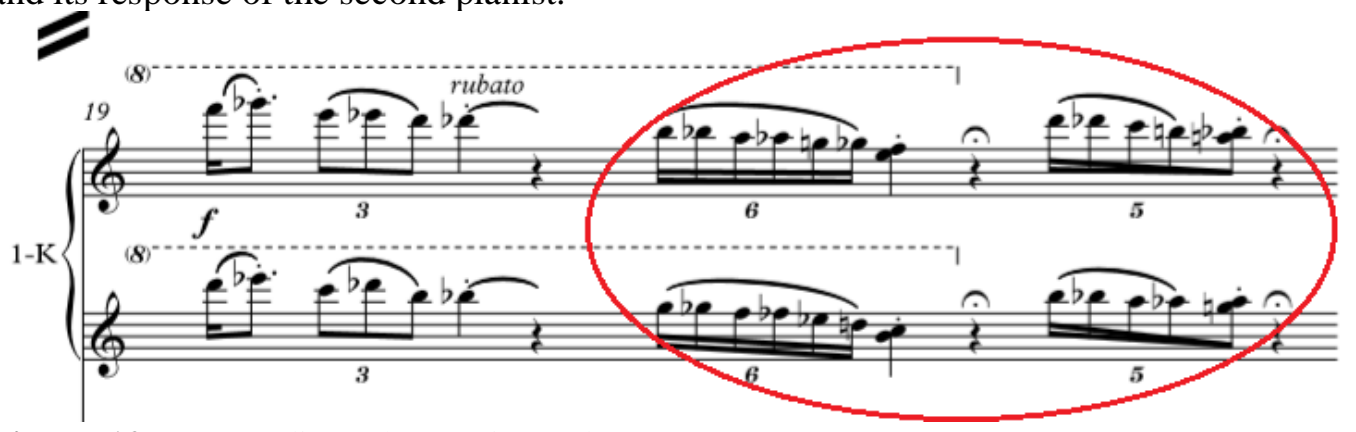

Figure 12: Descending Chromatic Scales at Bar 19.

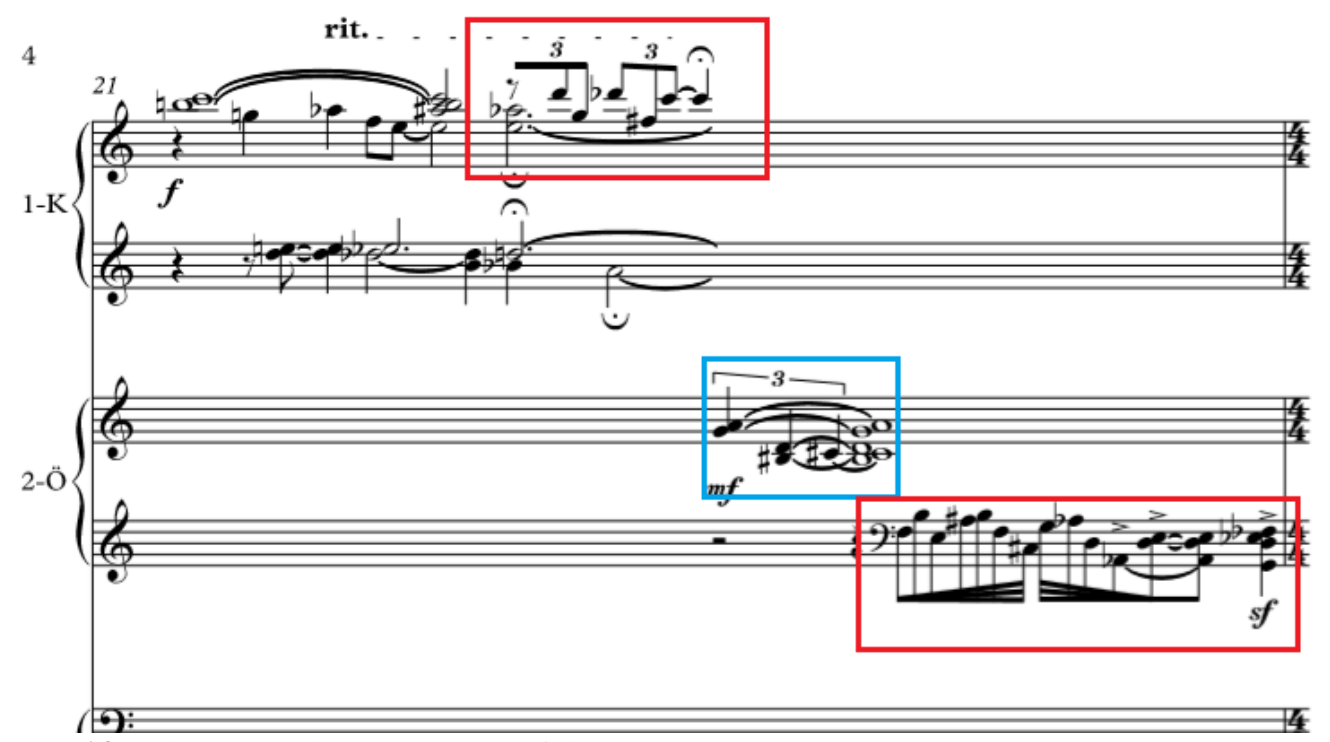

Figure 13: The Second Occurrence of the Fragment 1 at Bar 21. 
At bar 22 the tempo changes to $d=75$ in which the octaves of the third pianist create the third fragment of the Exposition part shown as Figure 14.

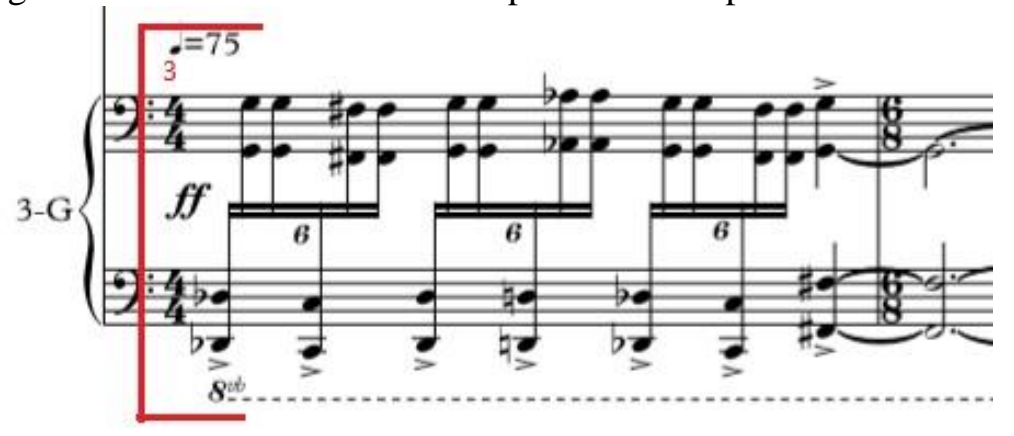

Figure 14: The Third Fragment of the Exposition Part at Bar 22 of the Third Pianist.

The second pianist adds quite static in nature chords that according to composer, they do resemble to the trumpet section of the orchestra. It is shown as Figure 15 below respectively.

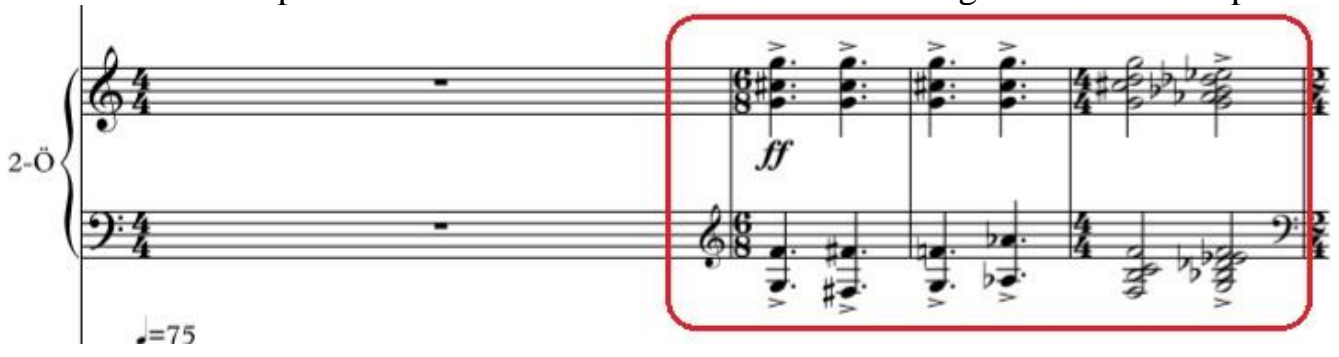

Figure 15: The Chords of the Second Pianist at Bar 22.

The empty sonority of the octave specie is unavoidable, stepping up to non-triadic collection (such as sus $5 / 4$ dis-chords). The third fragment is presented once again at bar 26 respectively of the second pianist but with extension of motivic contour ending up with chords that underlines composer's signature: B - B b - G.

A new tempo sign at bar $28(\mathrm{~J}=60)$ is introduced as opening of the fragment 4 of the third pianist that constitutes major seconds. At bar 32 the process is transferred to the second pianist that crates "call-response" effect. The prominent major second interval (A $b-\mathrm{B} b$ ) transforms itself to a minor second (B-C) giving grotesque character of the movement that is shown as Figure 16 below.

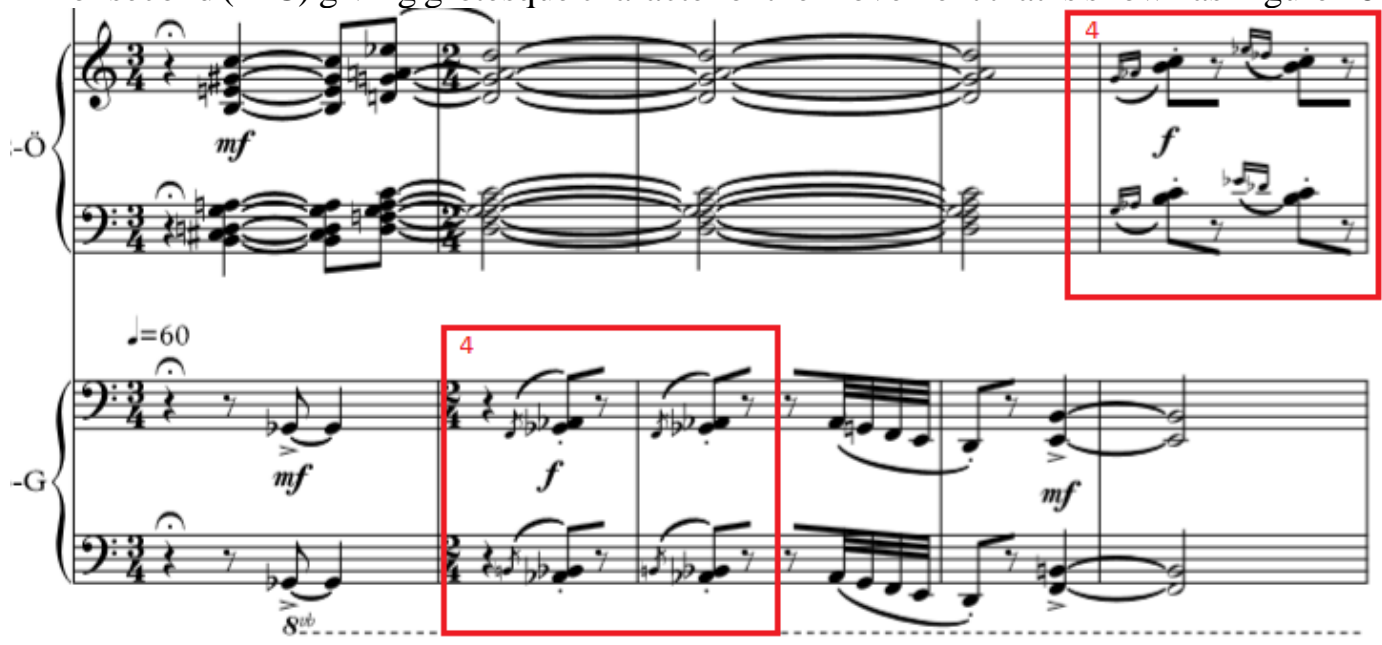

Figure 16: The Fourth Fragment of the Exposition Part.

With the entrance of the unison passage of the first pianist, the Exposition part concludes its statement. Bars 35, 36, 37 and 38 are a sort of codetta part where the composer does not forget to insert his idea of having a unifying motive - in this case, his signature. 


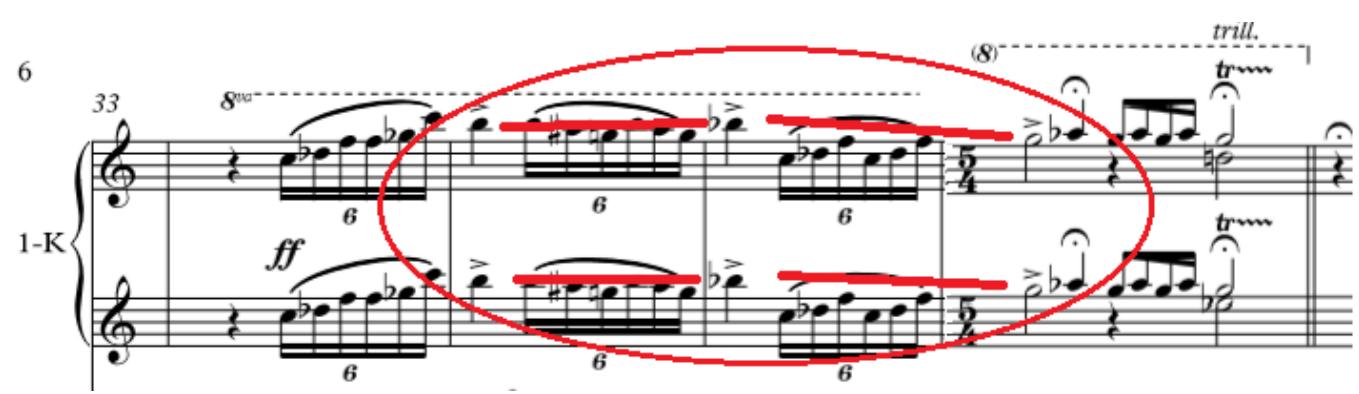

Figure 17: The Unison Passage of the First Pianist's Statement.

The Development part starts at bar 39 with clear asserted (B b - B - G) motive - the signature but slightly deformed from its original type. It is shown as Figure 18 below.

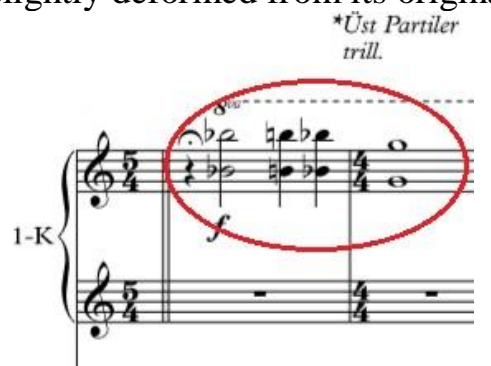

Figure 18: The Signature Motive of the Development Part.

At bar 42, three pianists play clusters in non-defined pitch collection. The sonority is tremendous and portrays the first layer of the development process which is shown as Figure 19 below.

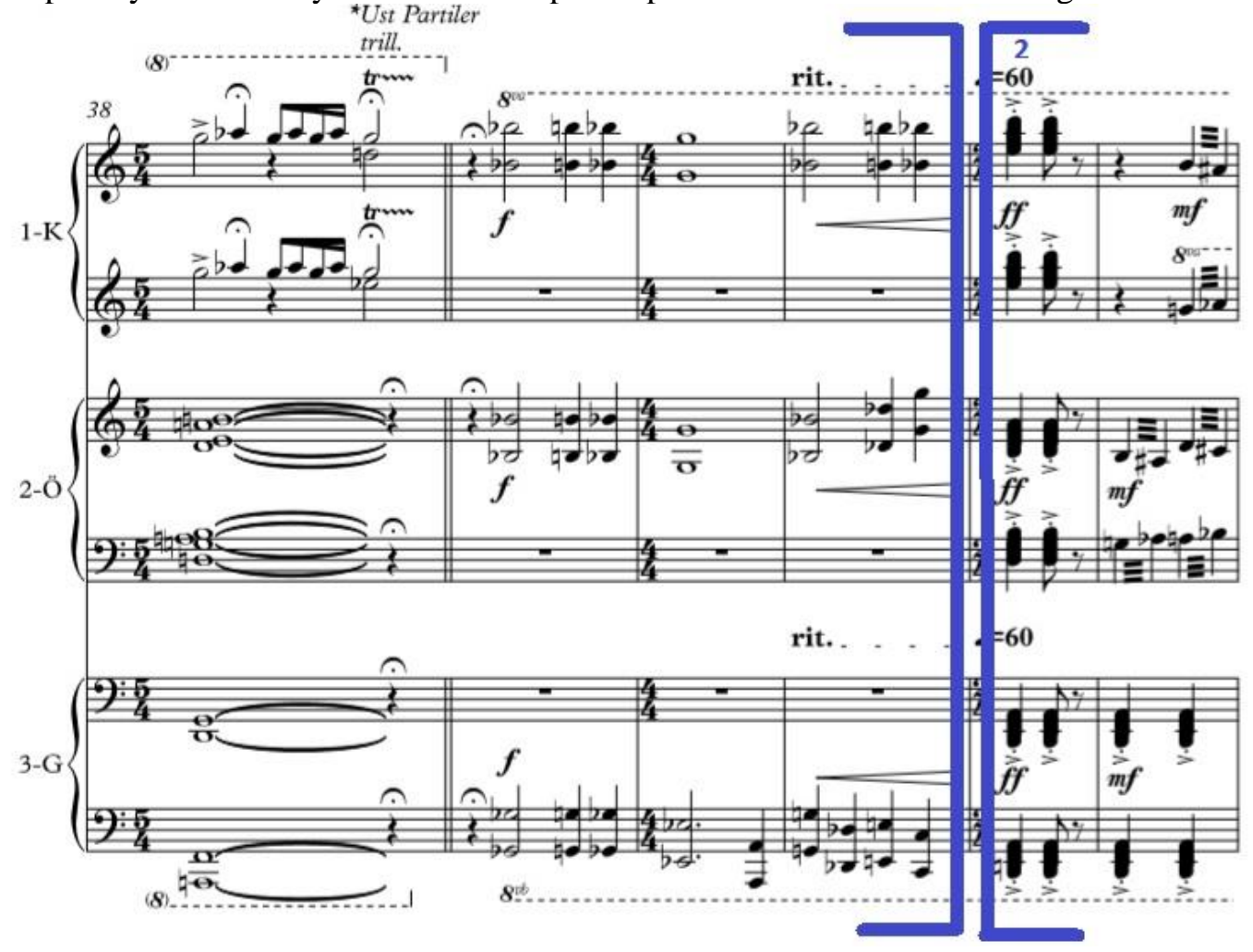

Figure 19: The Development Part.

Leaving this context to the third pianist, the other two presents the descending tremolandi figure of bar 13 creating the second layer of the movement. At bar 46, a new melodic line of the first pianist is introduced, which is borrowed theme of bar 29 that also bears small motivic elements of signature shown as Example 20. 

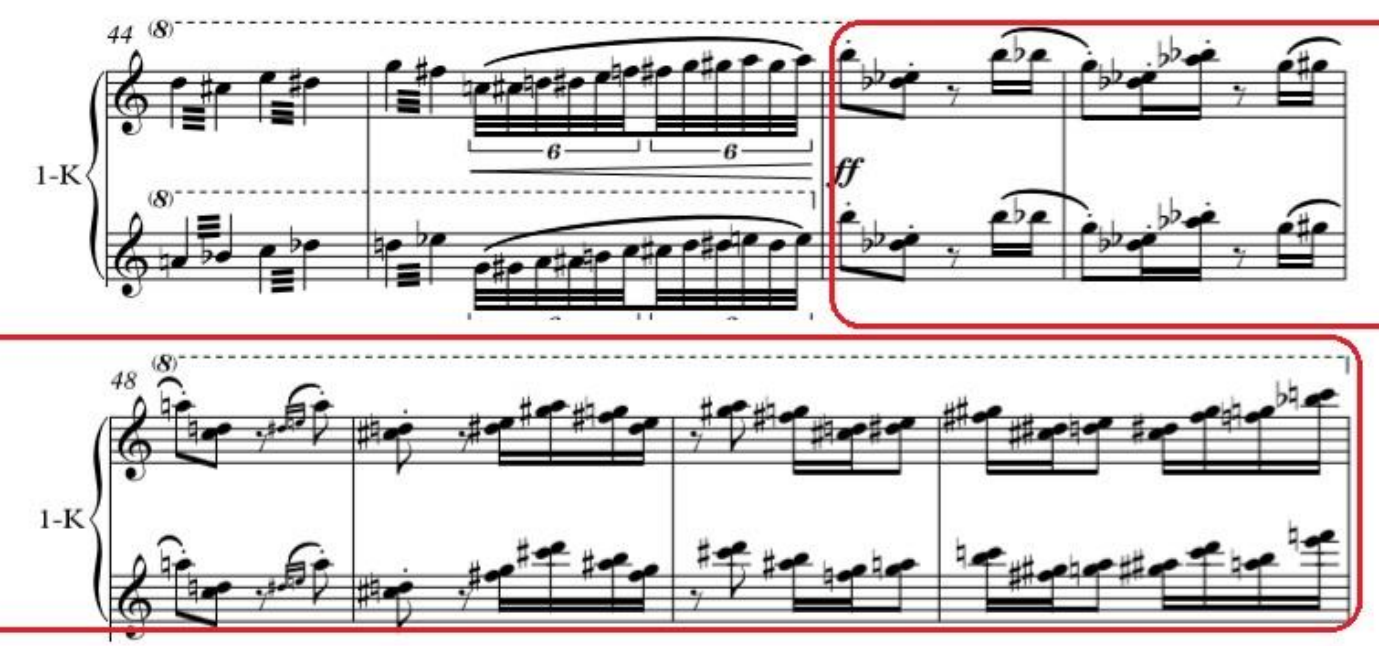

Figure 20: The Grotesque Theme Consists of Seconds at Development Part.

From bar 46 on, we hear three layers simultaneously, which are elements previously exposed. Each layer has its own internal development and at bar 52 there is interchange of the roles of the pianists like the clusters of the third pianist is now played by the first and the basic motivic element (the signature) is played by the third (Figure 21), where the second pianist continues to sustain the tremolo passage in the middle register.

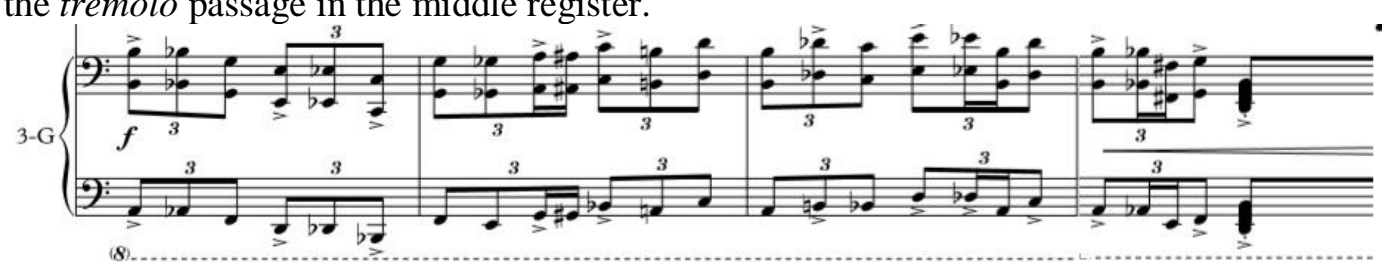

Figure 21: The Contrasting Idea of the Development Part.

At bar 56, another role change occurs in-between the first and second pianists. The static pulsation of the clusters while tremolo passage moves up to the first pianist and the grotesque theme that bears small signatures are now the primary elements of the second pianist shown as Figure 22 below.

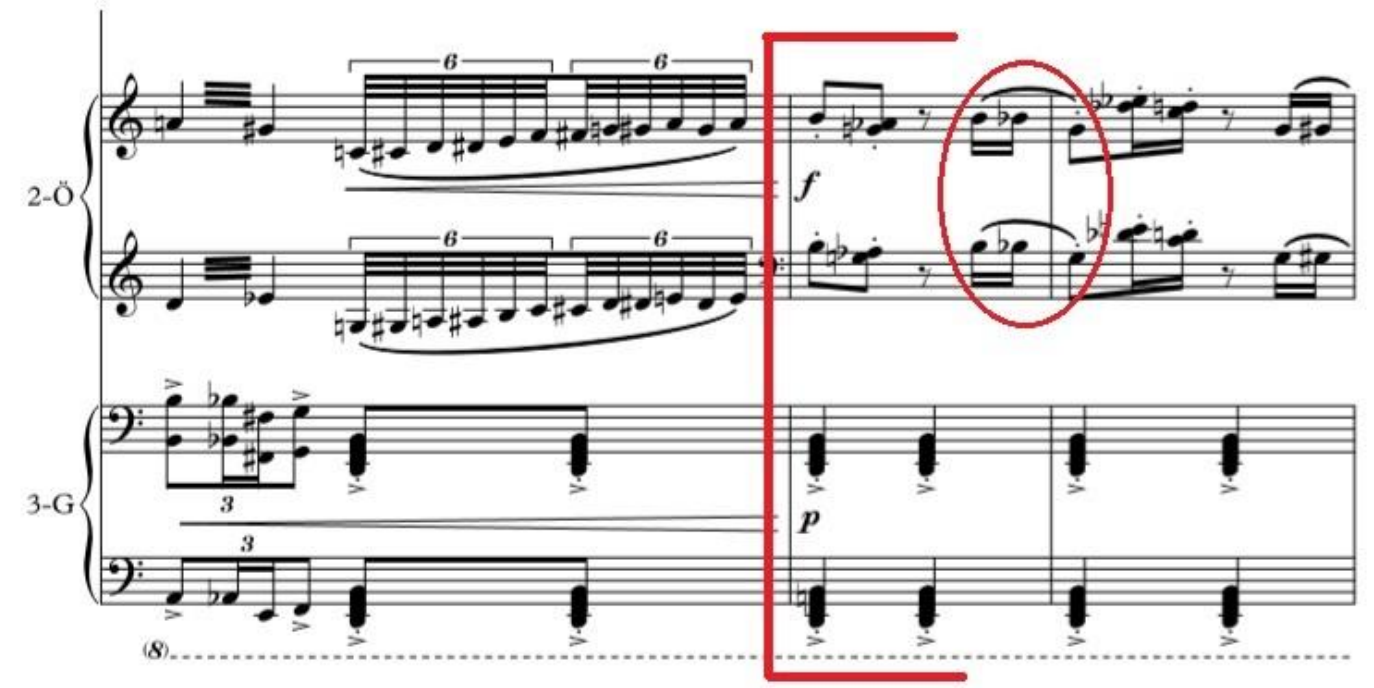

Figure 22: The Role Changing of the Development Part.

At bar 69-second downbeat, the first pianist and the second one are coming together interpreting the same musical outcome in which the third pianist continues her/his rhythmic pulsation in a duple meter. As shown in Figure 23, there we witness the transition between the layers and gestures. There are cymbal effects on the clusters at this place. 


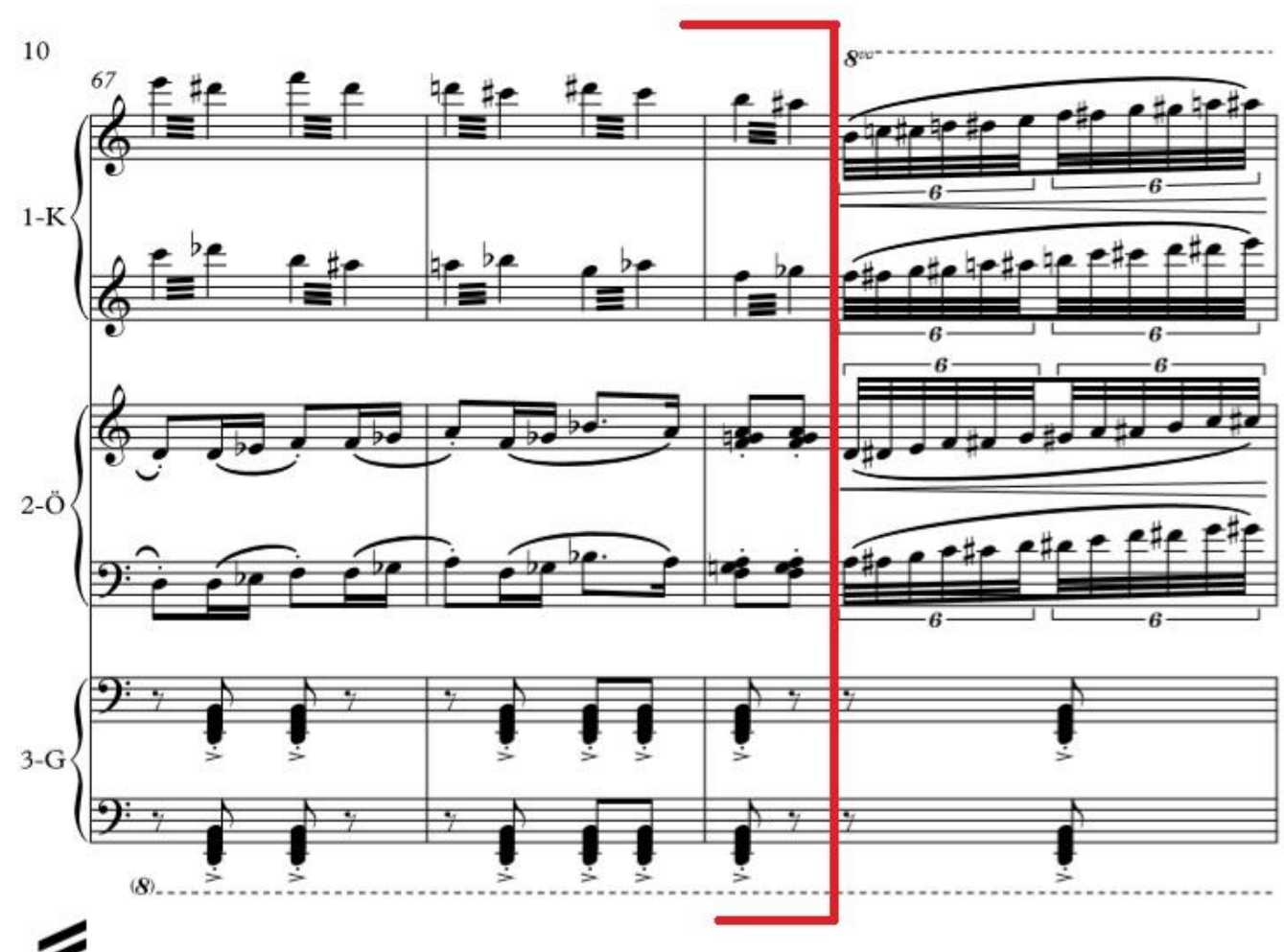

Figure 23: The transition Part of the Bars 67-68-69.

At bar 74, the grotesque theme bound on seconds is juxtaposed once again moving the tension towards dance-like tune, which ends at bar 78 with the arpeggio figure played by all three pianists reaching its climax at bar 81 . It is shown as Figure 24.

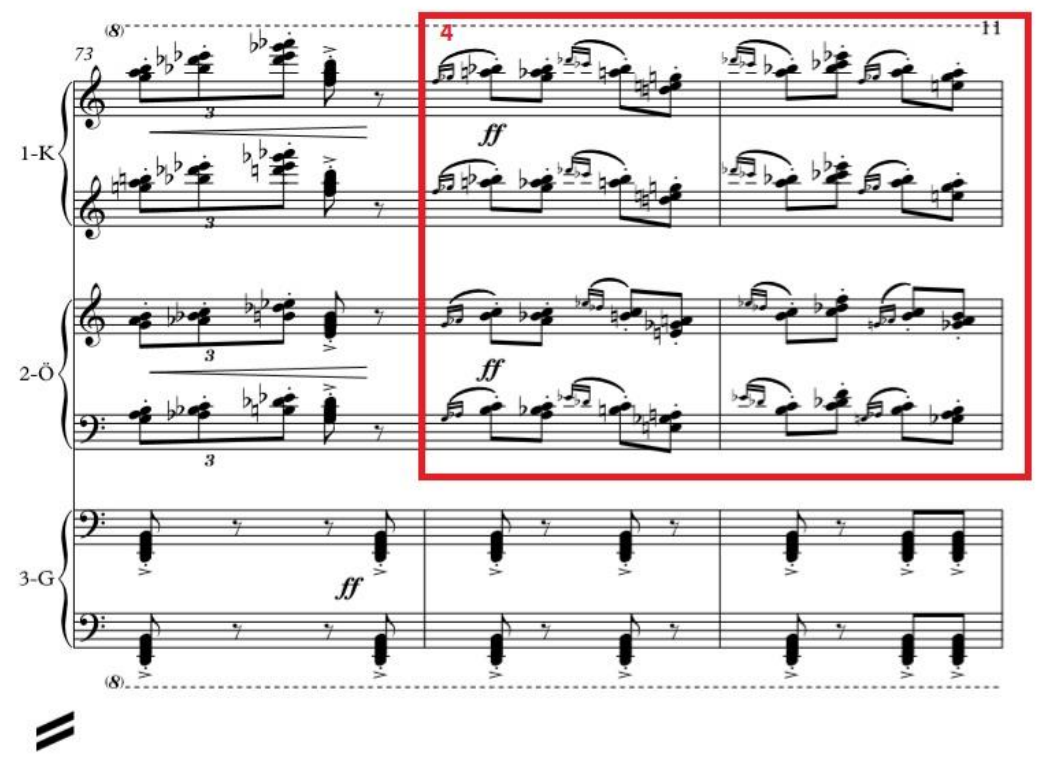

Figure 24: The Dance-like tune of Development Part at Bar 74.

After bar 84, the sustained tremolo passages are transformed to shorter segments interrupted by clusters, which are demonstrated by the first and second pianists. There are short occurrences of the signature motive (B-B b-G) on the third part, which is shown as Figure 25 below.

The third pianist together with clear punctuations of the signature performs the grotesque theme. Juxtaposing those elements each time on a different player creates dynamic developmental process where the listener experiences arbitrary functions of the changing elements not only in register as a coloristic effect but also as linear cross-cuts that stabilizes its mosaic structure. 


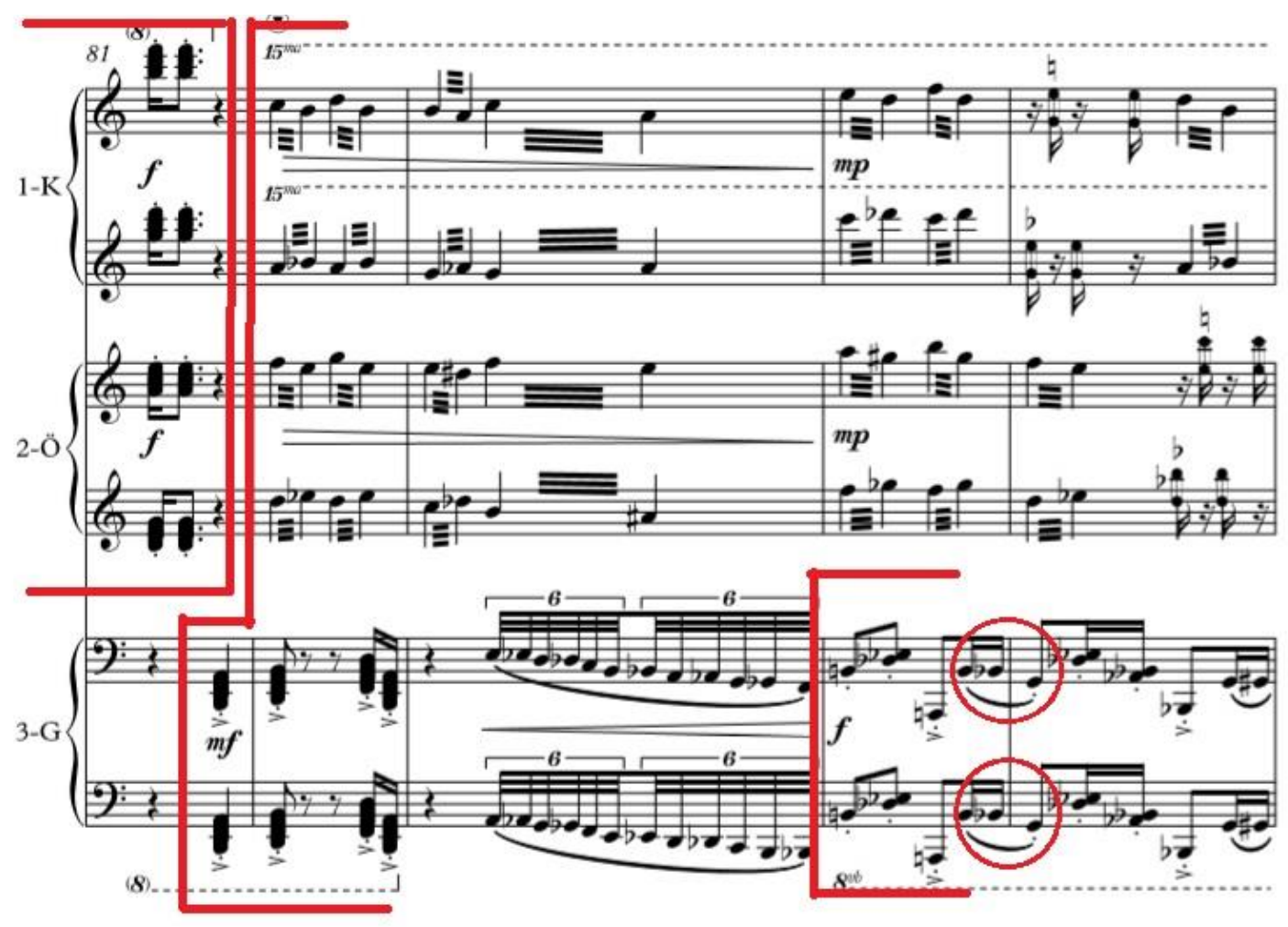

Figure 25: The Transformation of Layers and Small Motivic Elements of B - B b - G (The Signature Motive).

While changing the layers in-between the players there we can assert three main motivic elements: (1) The dance-like grotesque theme; (2) the tremolo, which creates unstable chromatic motion in its inner formation; and (3) the cluster chords that at bar 57 changes to triplets unison melody. This procedure is shown as Figure 26 respectively.

It is very crucial to note that at bar 97 shown in Figure 26 the B-B b-G signature motive appears once again played by the third pianist after the cluster section and the same motive transposes to a fifth below creating E-E $b-\mathrm{C}$ motive. 

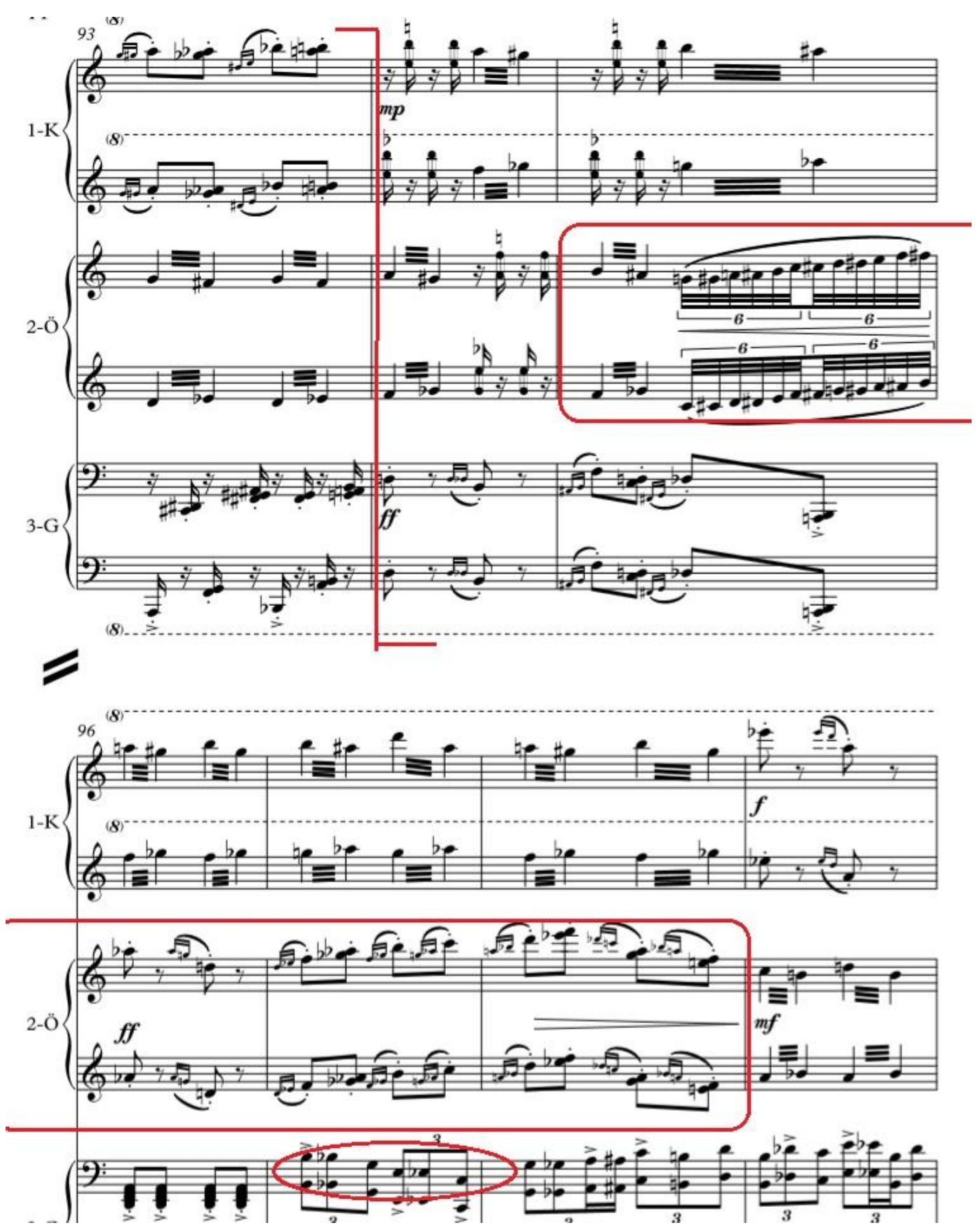

Figure 26: The Development Technique Used in Middle of the Development Part that Includes Signature Motive.

At bar 102, another climax passage occurs where all three pianists exaggerates the clusters of a gradual crescendo. At this point, all the performers have the same role in equal distribution of the dimension. The process is shown as Figure 27 below.

Research Article - This article was checked by Turnitin

Copyright (C) The Turkish Online Journal of Design, Art and Communication 


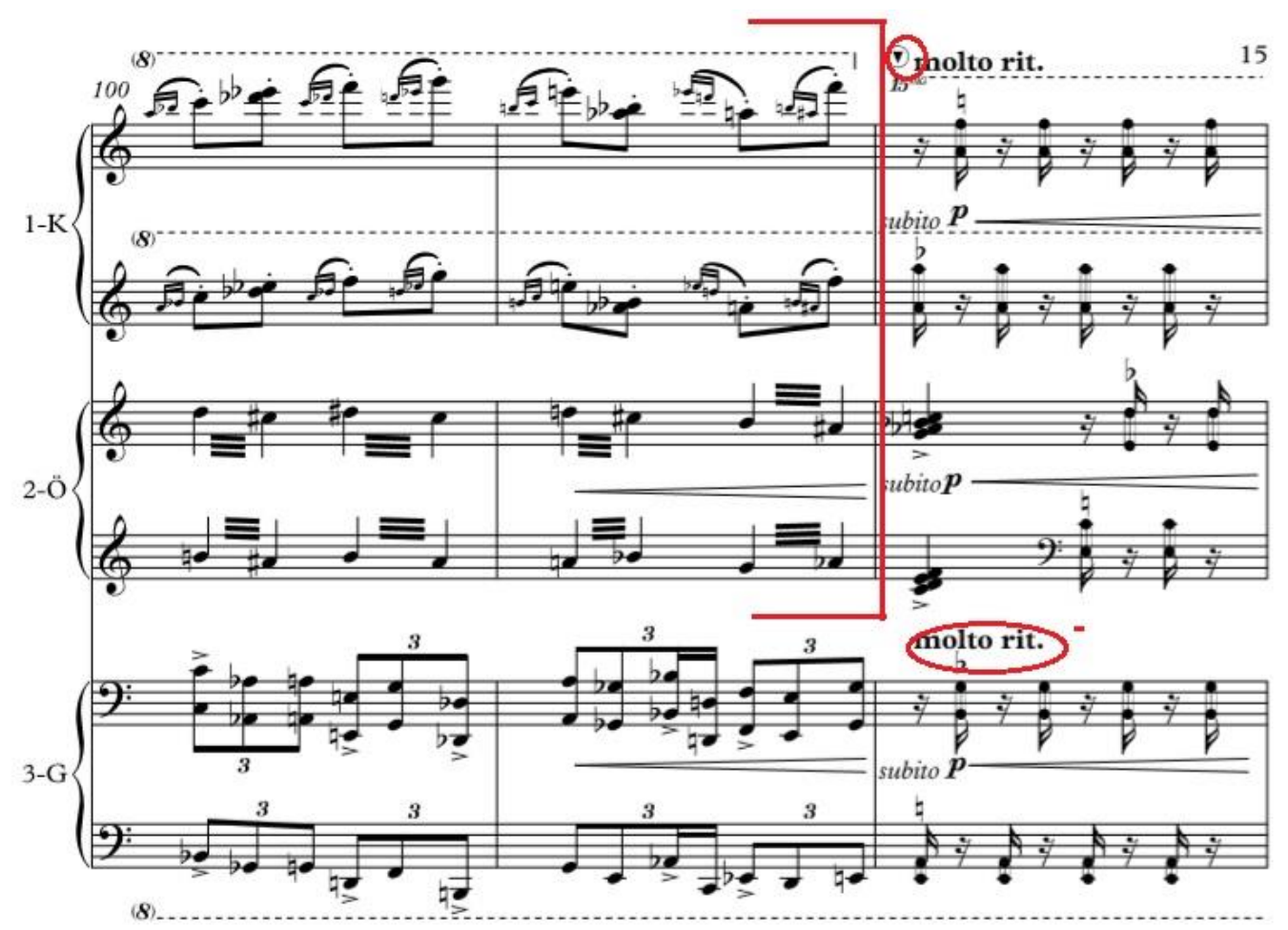

Figure 27: The End of Three-Layer Structure and the Beginning of Vertical Usage of Cluster performed by All Three Pianists.

The overloaded pitch material of the non-defined cluster material simplifies itself using single melodic line in unison fashion for all players at bar 107, which is shown as Figure 28. The unison playing style found frequently in jazz is proposed by Oguzhan Balc1 as a continuation of the musical process (personal communication, January 23, 2018).

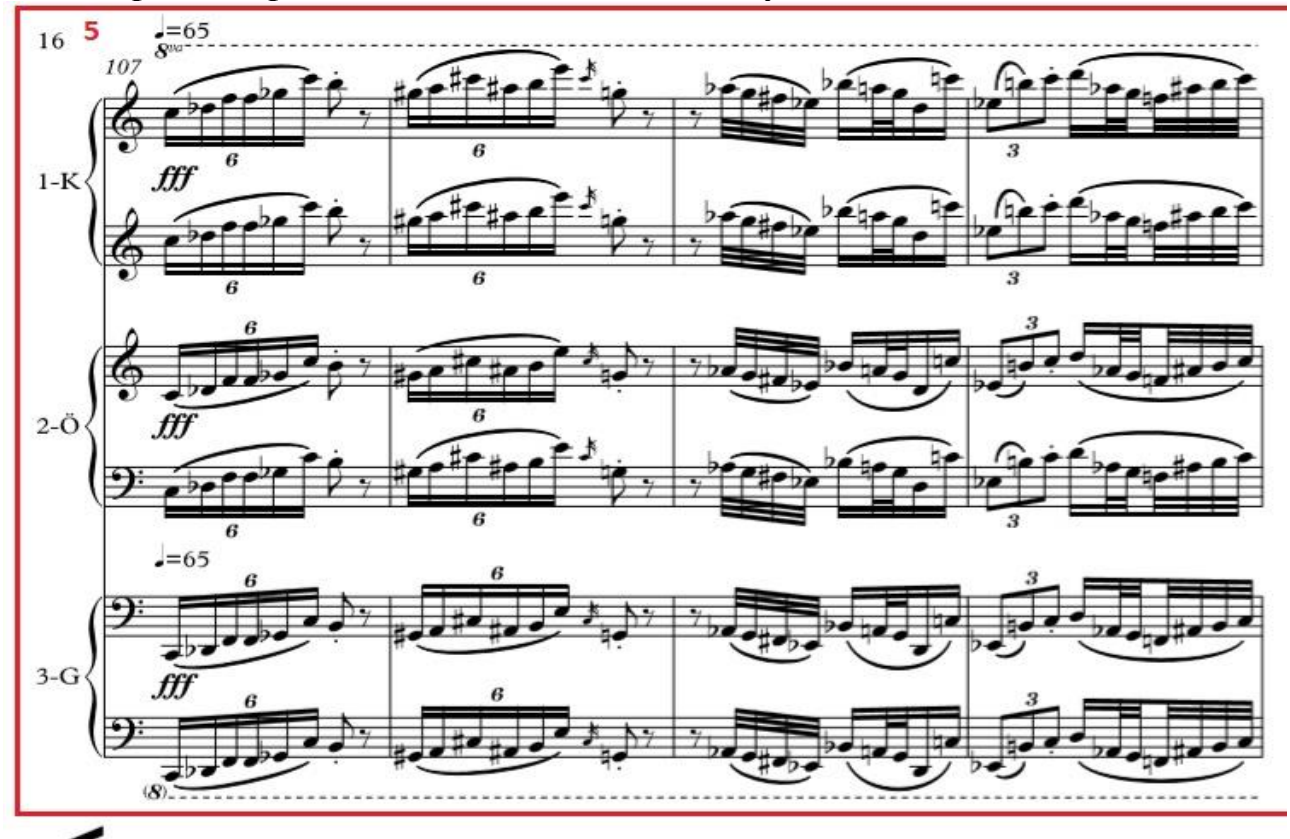

Figure 28: Unison passage of the melodic contour at bar 107.

The texture resembles to music of a jazz band, where usually the unison passage creates an important place for aural stability. This passage is coined as Fragment 5 by composer himself and at bar 113 the signature motive appears as a conclusion of the statement shown as Figure 29. 


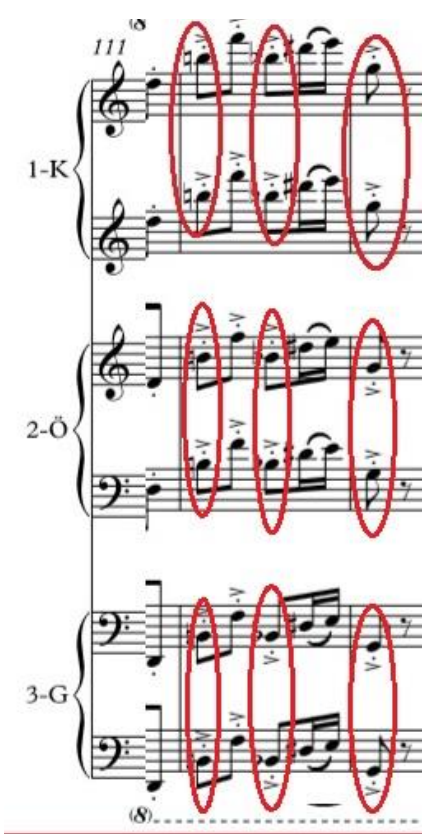

Figure 29: The Signature Motive at bar 113 in Unison Fashion as a Conclusion of the Statement.

At bar 116 the first and second pianist plays the cluster chords in which the first pianist uses black keys and the second one uses the white keys of the instrument. According to the dynamic range of these clusters calmer sonority creates significant contrast between the music that was going on and the recent appearance of hesitation which is shown as Figure 30.

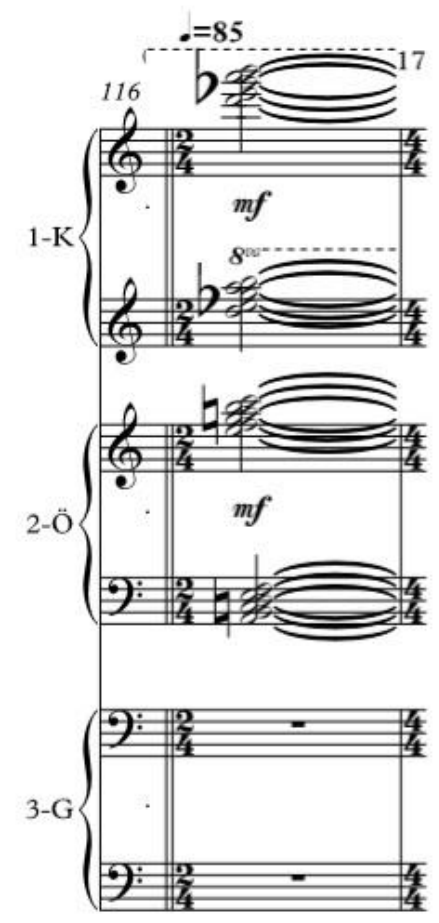

Figure 30: The Clusters of the First Pianist and the Second Pianist at bar 116.

At bar 118, the third Fragment of the Exposition part is exposed together with the huge cluster chords of the first and second pianists.

At bar 126, second pianist joins the third one augmenting the third Fragment and diminishing the cluster section. Here we may assume the working out process as moving between the segments and giving different value to the layering process. At bar 128, the third pianist leaves the Fragment 
3 and joins the first pianist's exhibition of the cluster section where the same process appears once again but in different strata. At bar 128, clusters continues to expose the signature motive but in different pitch material shown as Figure 31.

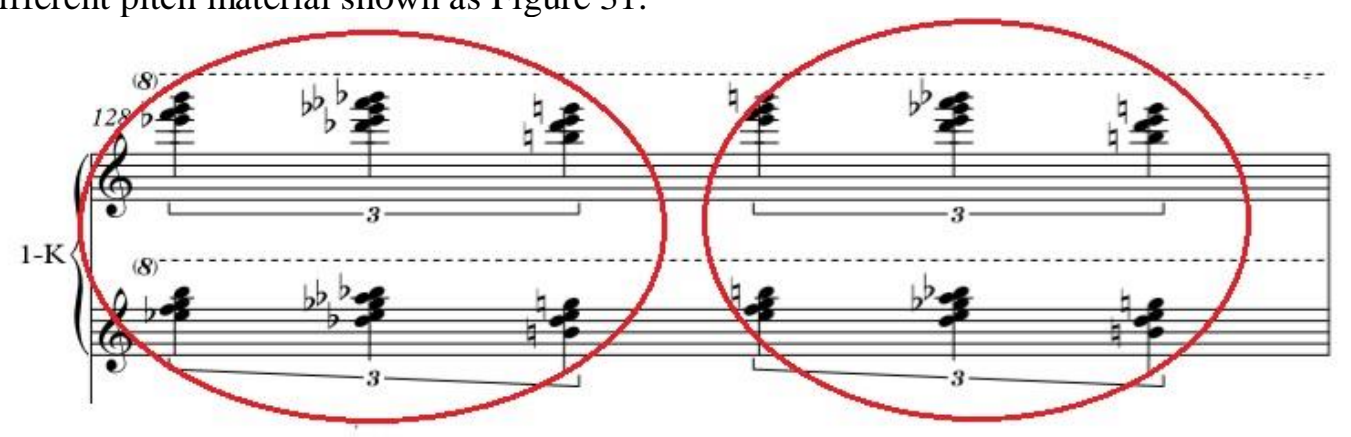

Figure 31: The Signature Motive of the First Pianist at Bar 128.

The abounded cells of the motivic expression of the signature are found also in bar 129 shown as Figure 32 below.

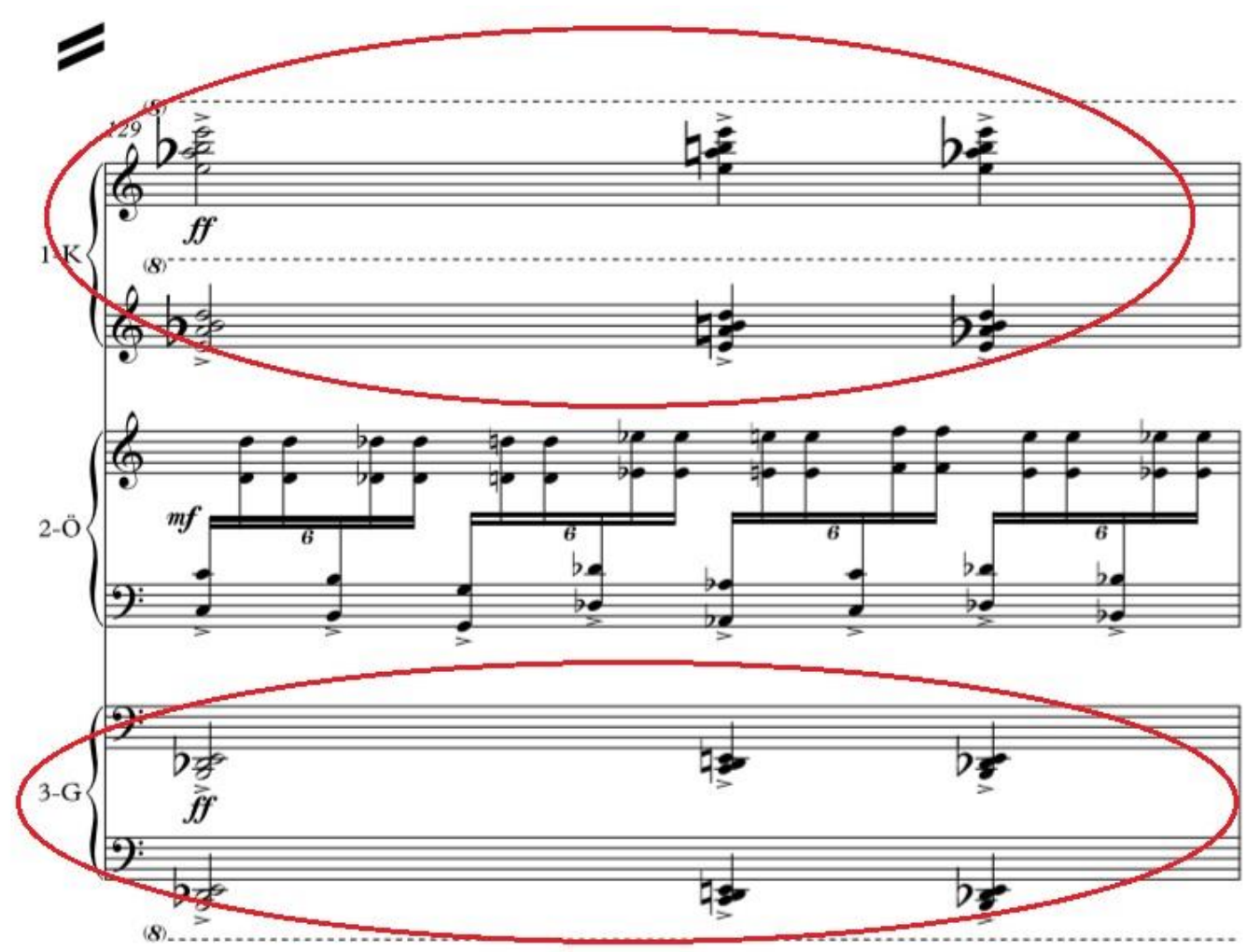

Figure 32: The Signature Motive played by the First Pianist and the Third pianist at bar 129 . At bar 133, the clusters get faster reaching another climax that concludes the Development part of the piece, which is shown as Figure 33. 


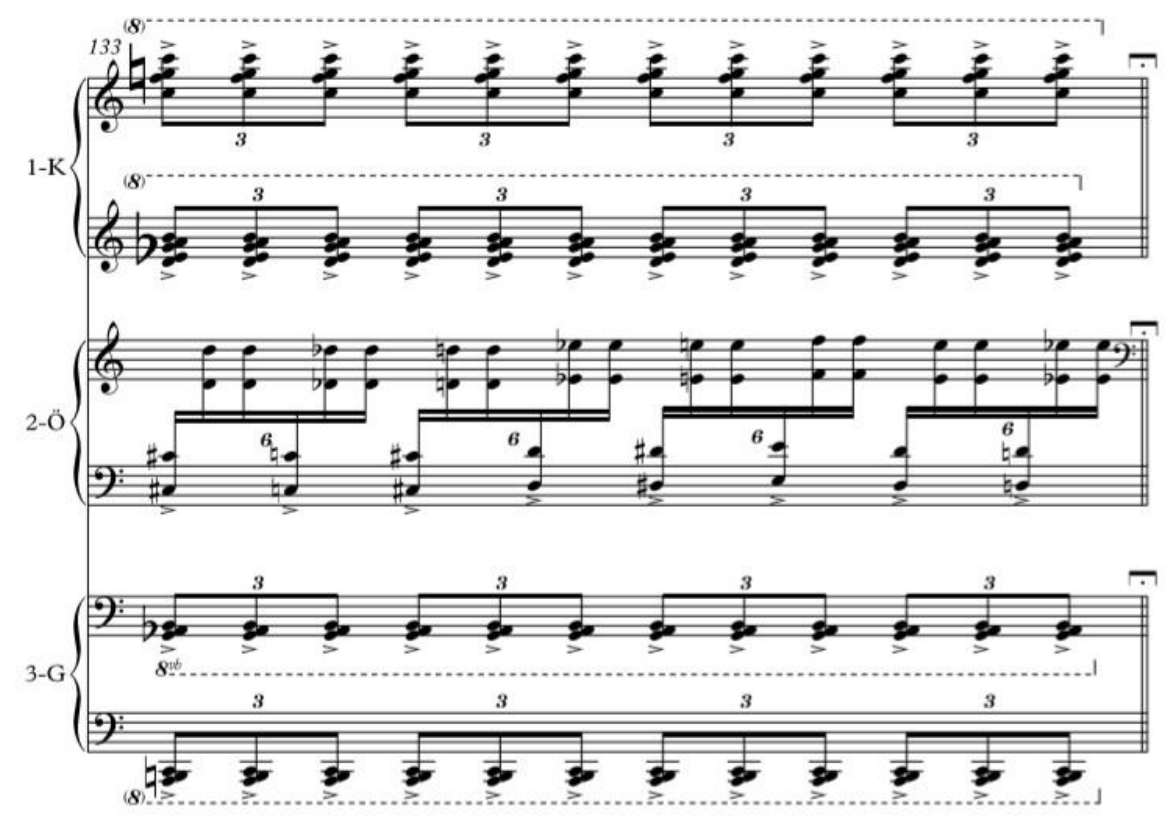

Figure 33: The Acceleration of the Clusters Reaching a Climax at bar 133.

Bar 134 is the place where the Bridge part starts. The indeterminacy is the primary element of compositional process. It is named as Bridge because there is completely new approach towards music. The composer gives brief indications on the score and this part describes raindrops together with a thunder. Many extended techniques are introduced in terms of reaching more sophisticated sonority. For example, the third pianist makes glissando effect with her/his nail on the strings of the instrument while the first pianist imitates the raindrops on the high register keys of the instrument. From single notes (single raindrops) to doubleones in a second apart the rain gets faster while the gestures accelerates. The movement's opening section is shown as Figure 34. The extended techniques used in that particular place are suggested by Oğuz Usman, so this is how it took its shape (personal communication, January 23, 2018).

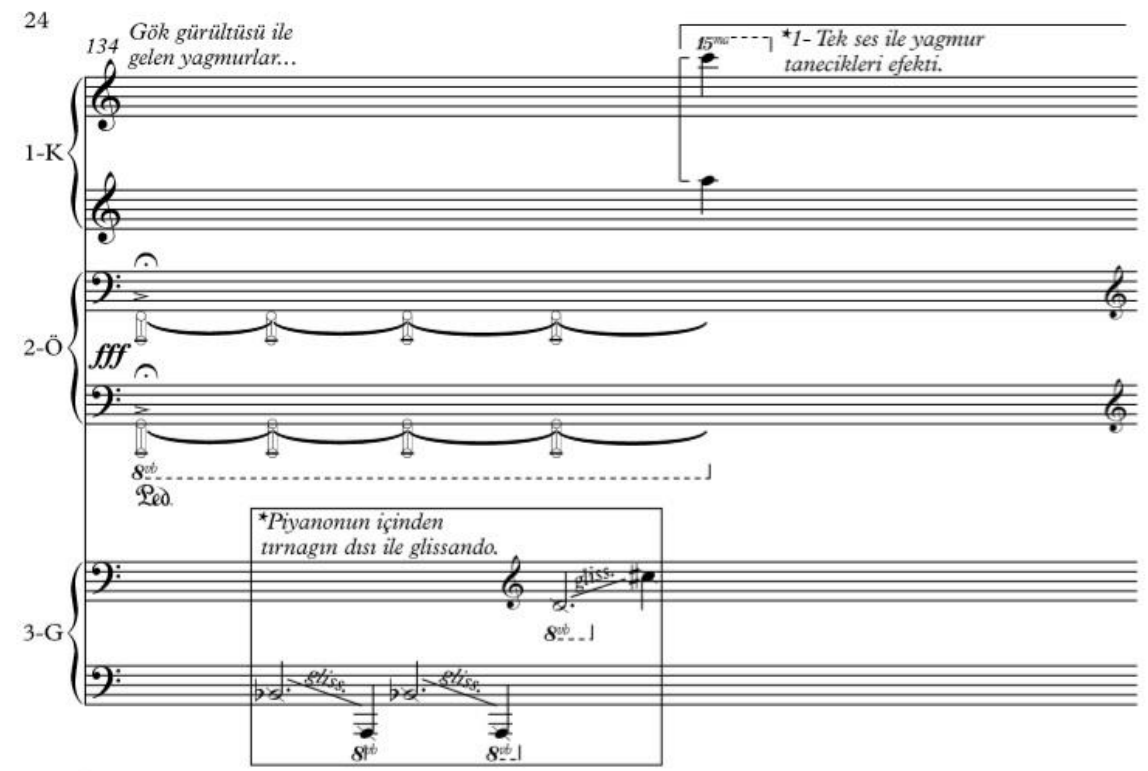

Figure 34: The Bridge Part of the Piece at Bar 134. 
At bar 168, there are huge clusters in a very loud dynamic range that try to describe a thunder as a natural phenomenon of the sound event, which is show as Figure 35. The delay of the cluster tremolos are described as timpani-roll effect of the orchestra by the composer himself.

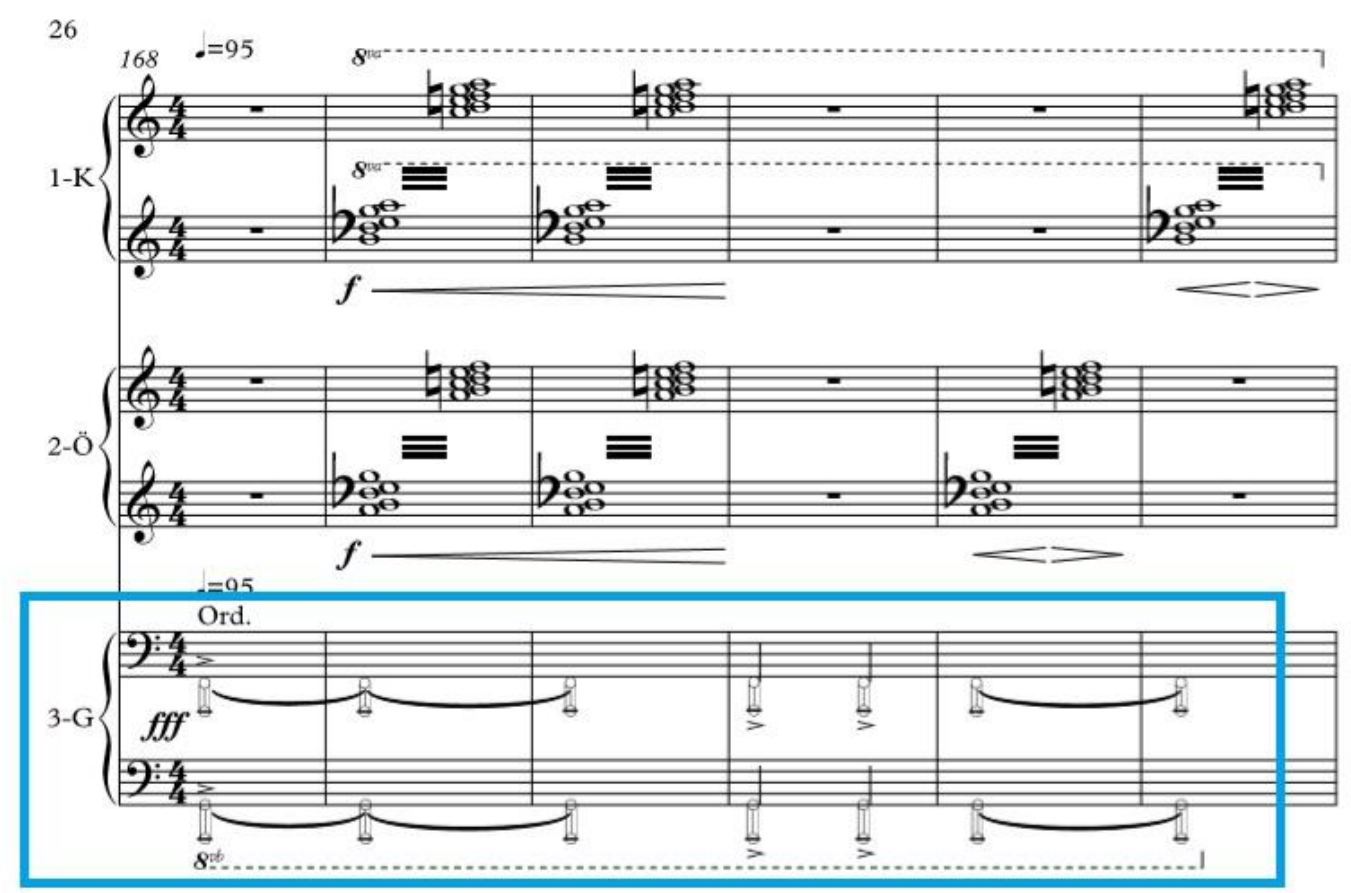

Figure 35: A Thunder Effect of the Third Pianist at Bar 168.

At bar 181, there is Recapitulation part of the piece. The B and C pitches are giving clear entrance of the previously introduced musical element of the Exposition part at bar 11. The G-A b-F-E melodic unit is once again presented but with the sevenths of the first piano, which according to composer they describe the anxious state of the heart. The opening of the Recapitulation part is shown as Figure 36 respectively.

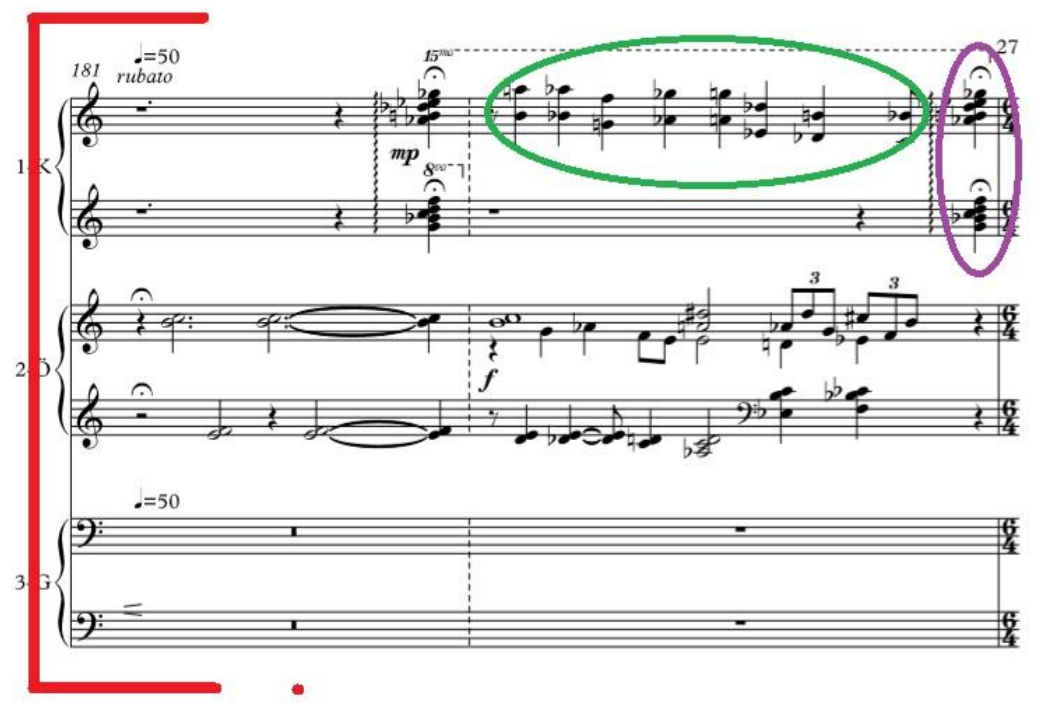

Figure 36: The Recapitulation Part of the Piece at Bar 181.

At bar 183, three-note signature motive is presented once again in his accurate pitches. It is shown as Figure 37. 


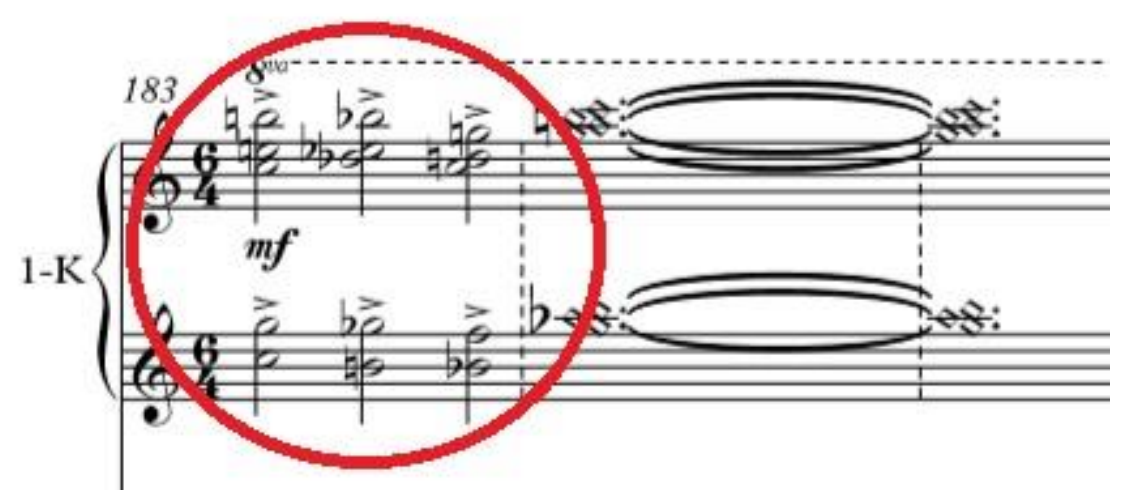

Figure 37: The Signature Motive of B-B b-G at Bar 183.

Using some other extended techniques, such as sustained harmonics are quite prominent in this part. The Recapitulation part also traces completely three new motivic elements devoted to Özgür, Kandemir (Figure 38) and Gökhan (Figure 39) that this piece is dedicated for. Composer uses alphabetical order as applying each letter to a pitch and creating a short melodic fragment out of the name that bound to a musical nomenclature typical for B-A-C-H. This process is also quite well-known among composers like Robert Schumann (ABEGG Variations), Maurice Ravel (A Menuet Sur Le Nom de Haydn), Kamran İnce (NKG Variations) and many more.

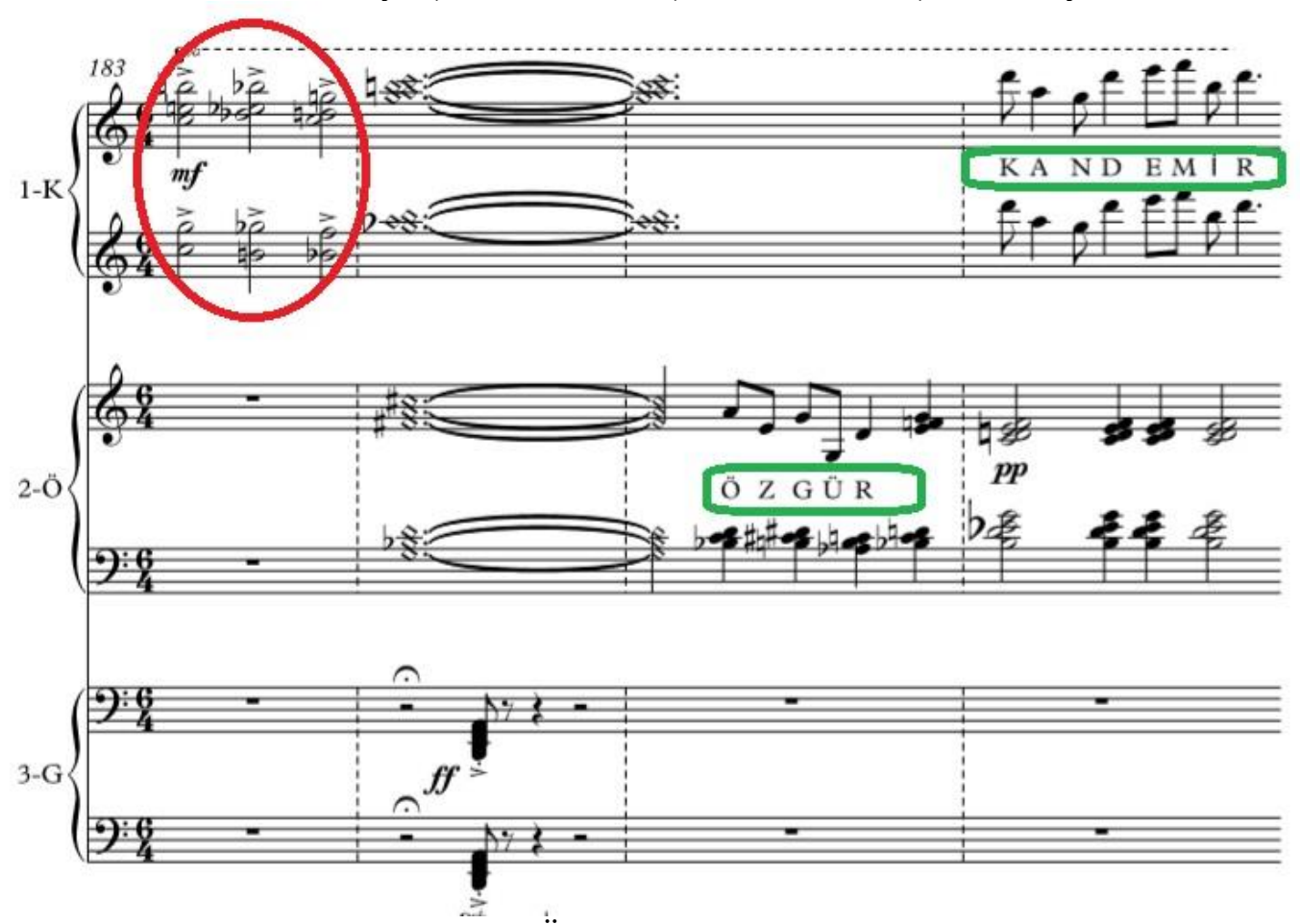

Figure 38: The Signature Motives of Özgür and Kandemir. 


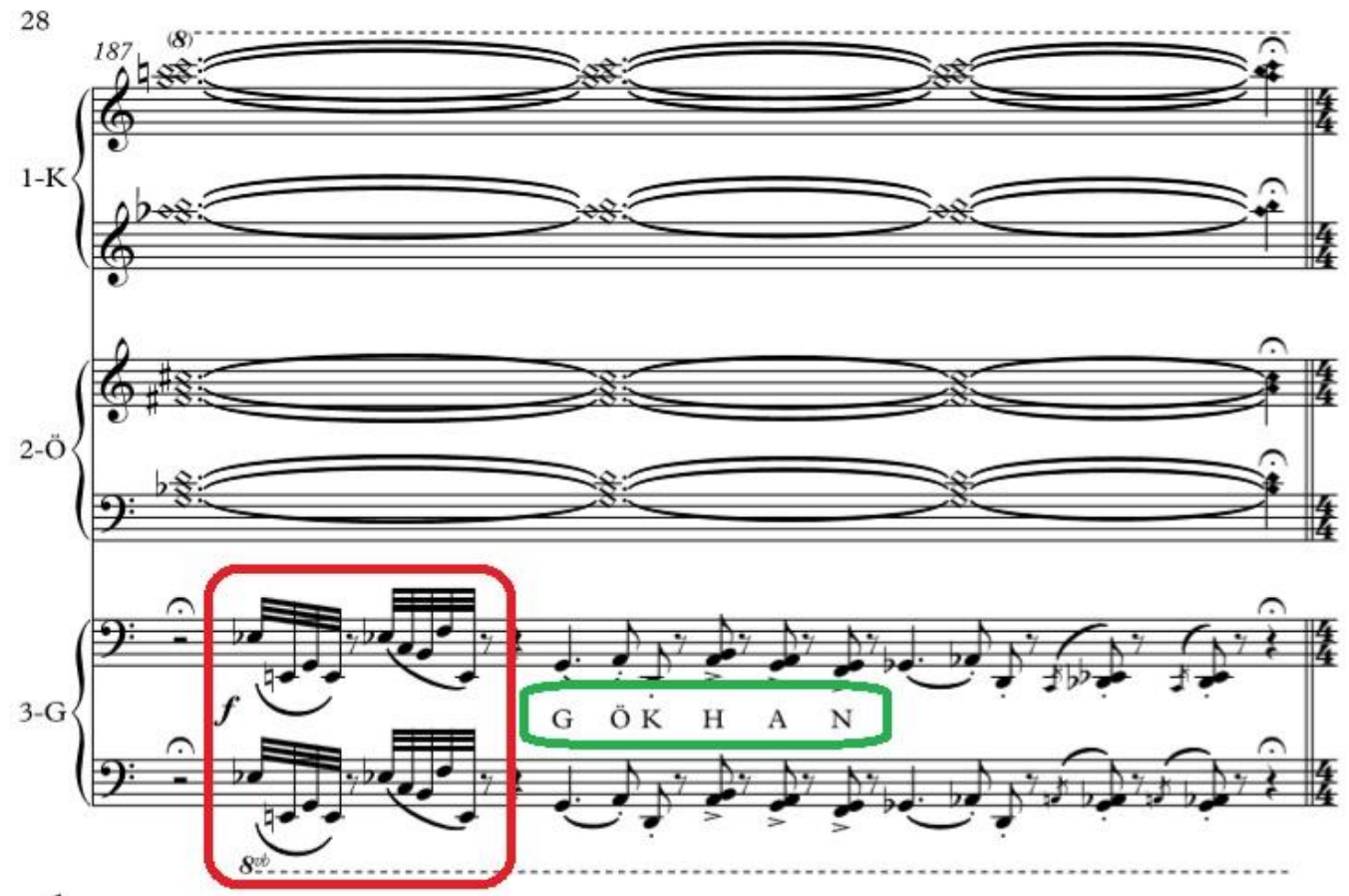

Figure 39: The Signature Motives of Gökhan and Schnittke.

Introducing shortly the entire motivic construction at bar 188, composer presents his signature motive twice transposed on $\mathrm{E} b$ and with the last four bars, abruptly juxtaposed clusters concludes the piece. The signature motive on $\mathrm{E} b$ is shown as Figure 40.

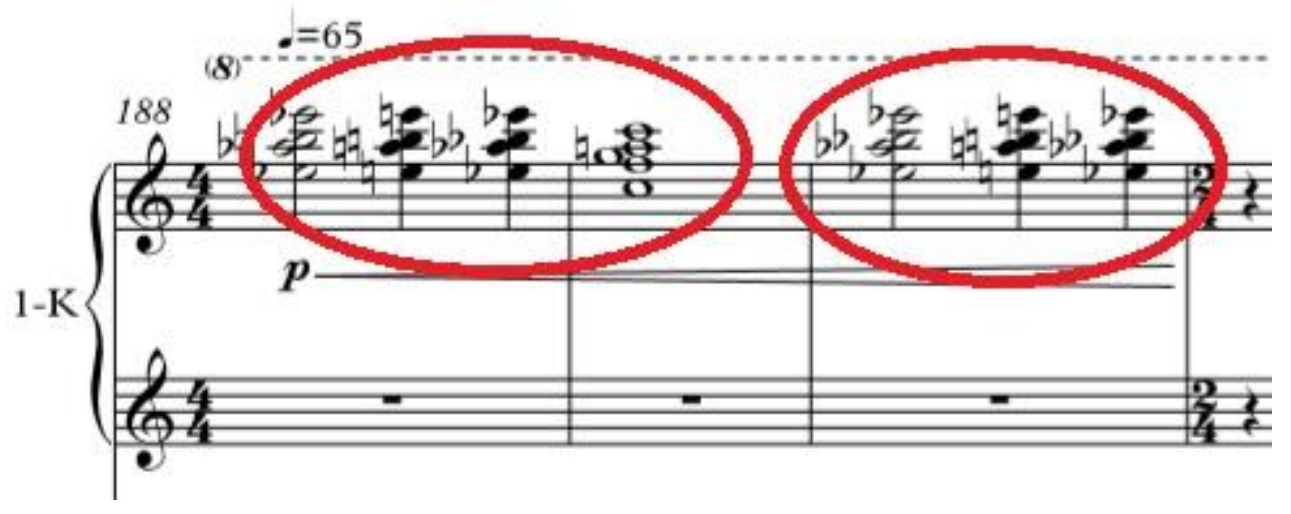

Figure 40: The Signature Motive on $\mathrm{E} b$ at Bar 188.

The last bar is only a rest with fermata that portrays the tomb of Schnittke (Figures 41 and 42). Composer states the following explanation at the end: "In a respect of Schnittke..." 


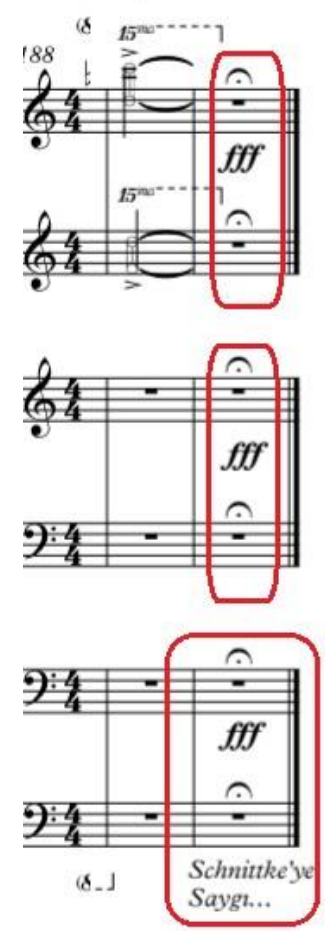

Figure 41: The Last Bar of the Piece which is devoted to the Tomb of Schnittke.

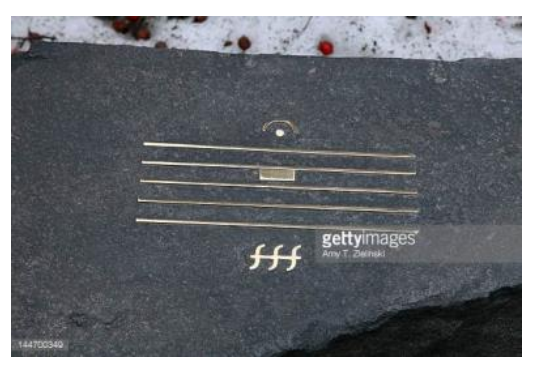

Figure 42: The Tomb of Schnittke (access date 17.01.2017).

In general, examining the composition in terms of basic playing techniques there are unisons (ex. $1^{\text {st }}-8^{\text {th }}$ bars), rubato chords (ex. $9^{\text {th }}, 23-24^{\text {th }}$ bars), the sections that include octave appreciation (ex. $22^{\text {nd }}, 26-27^{\text {th }}$ bars), tremolos (ex. $13^{\text {th }}, 43-69^{\text {th }}$ bars), the passages that include fastness of some chromatic six-tuplets (ex. 78-82 ${ }^{\text {nd }}$ ), staccato passages, legato passages and many passages that include pedal techniques. Besides these basic playing techniques, many other extended playing techniques can be found throughout the score as well. For example, pressing the keys without producing any sound (ex. 184-185 $5^{\text {th }}$ and $187^{\text {th }}$ bars), : of chromatic clusters (ex. 134 ${ }^{\text {th }}$, $168-173^{\text {rd }}, 177-178^{\text {th }}$ and at the end $192-193^{\text {rd }}$ bars), ${ }^{2}$ clusters specified for only white keys or black keys (ex. $13-15^{\text {th }}, 52-55^{\text {th }}, 86-91^{\text {st }}, 94-95^{\text {th }}, 102-106^{\text {th }}$ ), $\mathbf{E}$ cluster chords that identified (random) pitches (ex. 42-51 $1^{\text {st }}, 55-82^{\text {nd }}, 89^{\text {th }}, 96^{\text {th }}, 191-192^{\text {nd }}$ bars) and gliss. glissando with the nail on the strings inside the instrument at marked sections (ex. $7^{\text {th }}, 134-159^{\text {th }}$ bars) are the techniques needless to be mentioned.

Besides these techniques explained above, composer wants to pay careful attention on the passages that are marked as ${ }^{-}$. For example, at bars $81^{\text {st }}$ and $102^{\text {nd }}$ the $15 \mathrm{ma} \ldots$ is indicated with this special sign in order to draw attention to the section that should be played two octaves higher that it is supposed to be just as $8 \mathrm{vb} . .$. that is marked at bar 126 that is offered to be played an 
octave lower than its actual range. The composer also wants to draw attention on bar 123 where he wants the exact pitches of the chord putting this special sign above the chord.

There are also special effects by the composer while playing the piece. For example, the staccatos at bar 15 should imitate the heart beat pulsation, bars 23-25 portrays the passage where the chords should sound like the trumpet section of the orchestra, bars 74-77 and 92-101 should be played in dance-mood like manner. Between bars 134-159 of the composition, the rain turns into a storm and it projects the trouble feelings that also manifest inner explosion of the soul. Composer describes the procedure with the following statement: "According to prescribed range of the pitch material press the keys randomly while improvising just like coincidentally occurrence of the raindrops". From bar 177 to 180 there are timpani effects during these four bars.

At the same place, there should be a thunder effect, which is a technique that is known also as a string piano in the literature. For that reason the appreciation of these glissandi should sound as a whole. In the playing notes of the beginning of the score, the composer writes: "If the note in entrance is not suitable to be played, choose the nearest ones in this case." On the meeting with the composer, he adds that this procedure was took shape with some suggestions of Oğuz Usman. The section should be considered also as taksim, a very familiar improvising form of traditional Turkish music and it is expected from the players to express themselves in that way. According to the recording's duration, which is $10^{\prime} 48^{\prime}$ ' in length, composer suggests ca. 11'-12'.

Finally, interpretation of this piece may be suggested considering the following words of composer related to the work:

"With this composition I tried to express the mess of Istanbul's inner world, the aggressiveness in transportation system "I reflected all boundaries of the Miniatures piece to Sky."

"I composed according to reach the performers, aiming them to expose good quality sound." (Personal communication, November 03, 2017).

“At bar $16^{\text {th }}$, firstly exposed the ascending passage is corrected by Eray Altınbüken. Especially the raindrops effect was reconsidered according to Oğuz Usman's recommendations with using extended techniques respectively. The piece took its shape thanks to Eray Altınbüken, Oğuz Usman and Oğuzhan Balc1, all lecturers at Istanbul Technical University, with their suggestions." (Personal communication, January 23, 2018)

The Concert held on 12 April 2016 20:00, Çankaya Municipality Contemporary Arts Center is the event of the Turkish composer Hasan Barış Gemici whose composition 'Sky' (Gök) for six hands piano was performed. It was the World Premiere of the piece (TRT radio recording, October, 2016).

Hasan Barış Gemici (14.10.1996-) the composer was born in Bursa. He started his music education at 9 years old with mandolin lessons from Nejdet Kalender. He completed his high school education at Bursa Zeki Müren Fine Arts High School. He studied composition with Oğuzhan Balcı and Eray Altınbüken in composing department of ITU Turkish Music Conservatory entered in 2014, classical harmony with Oğuz Usman, and jazz harmony with Nail Yavuzoğlu, Turkish music with Feridun Öney and Yeşim Altınel Çoban and piano with Kandemir Basmacioğlu. He composed Three Miniatures for piano, Music Drunk for violin and piano (theme and variations) and Sonatine for flute and piano. Gemici continues his composition studies with Oğuzhan Balcı (personal communication, November 03, 2017). 

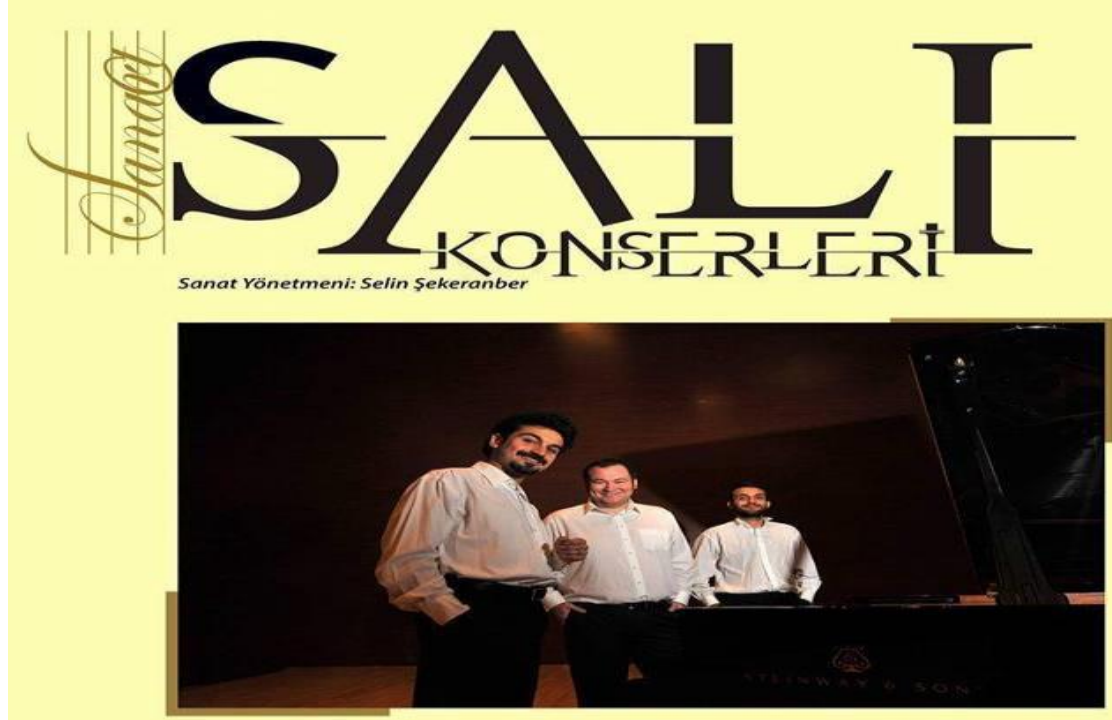

\section{| 6 EL BIR PIYANO KONSERI \\ Özgür Ünaldı, Gökhan Aybulus, Kandemir Basmacıoğlu}

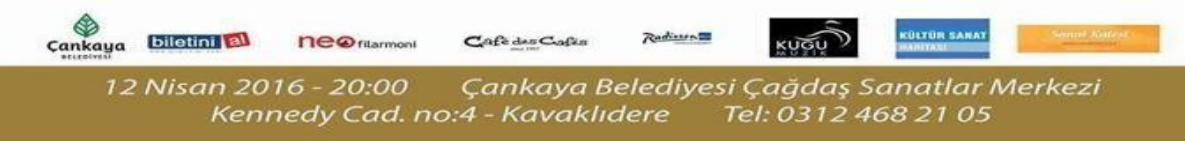

Figure 43: The Poster of the Concert on 12 April 2016 20:00, Çankaya Municipality Contemporary Arts Center.

\section{Konser Programı}

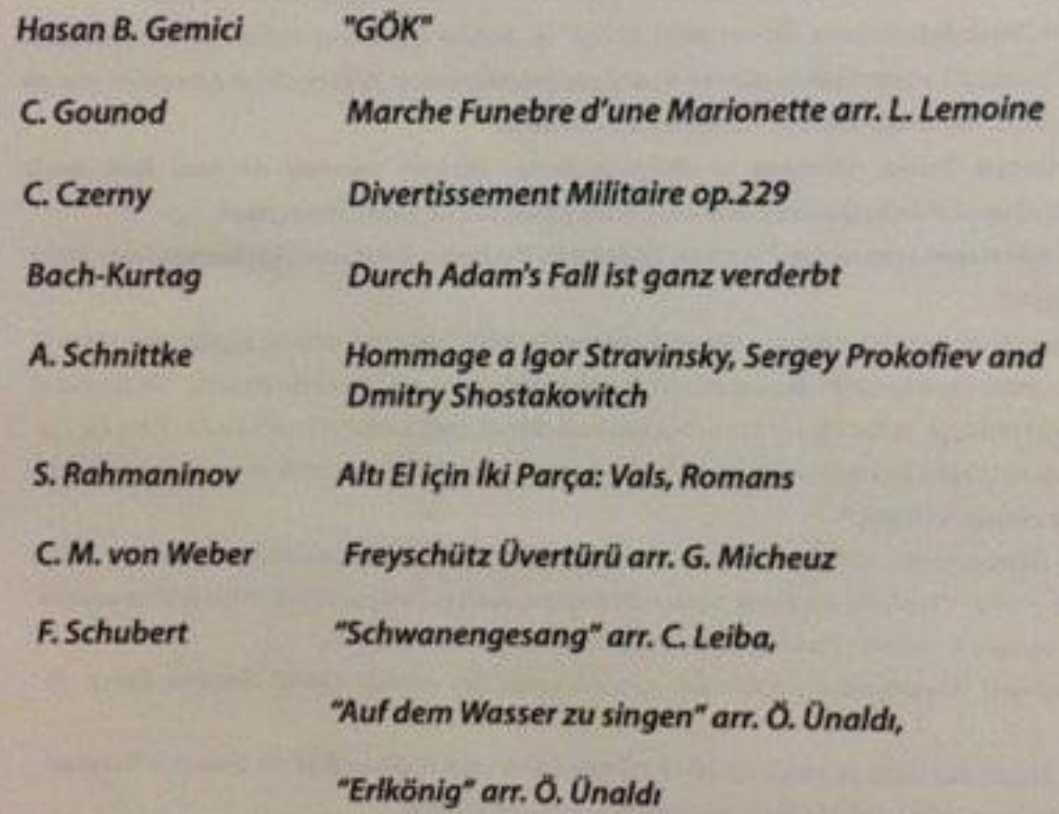

Figure 44: The Concert Program of the Concert on 12 April 2016 20:00, Çankaya Municipality Contemporary Arts Center. 
Program note of "GÖK" is as follows:

Gök 'Sky', this music is dedicated to Gökhan Aybulus, Özgür Ünaldı and Kandemir Basmacioğlu. It was written as a respect to the Russian composer Alfred Schnittke, influenced by his work 'Igor Stravinsky, Sergey Prokofiev and Dmitri Dmitriyevich Shostakovich' and it is written between May 2014 and April 2015. The music itself consists of 4 movements, which are not equal to each other. The music starts with the signature 'HBG' ( $\mathrm{B}, \mathrm{B} b$ and $\mathrm{G}$ ), which is the signature of the composer, and then the first movement, in the introduction section, which starts with distressing and aggressive insights, begins. When the introduction movement ends with the rebirth of the HBG motif, the second movement begins, and in this section all the musical insights in the first movement are enlarged and become more aggressive and the third movement bonds, which are the 'Rain from the Thunderstorms' here some of the techniques in the piano are used. In this movement, the storms break, the heavy rain starts to turn into a full rain, and the fourth movement is connected. In this section, we hear the motifs written for each pianist's name and the first two motifs of Alfred Schnittke. The music ends with the deformed state of the HBG motive (personal communication, November 03, 2017).

\section{CONCLUSION}

The signature motive of B - B b - G appears to be as an "idée-fixe" - a recurring theme or character trait that serves as a structural foundation of a work. This obsessive approach is found in many places of the composition. It is therefore; we find tight-knit formal design of the piece itself. In this respect, piano is an instrument that may produce multiple sonorities which reflects to the classical orchestra, for that reason composer aims to reach the timbre of the orchestra throughout many parts of his composition (like Figures 10 and 15 - timpani effect and the trumpet section). So many timbre colors are achieved from this single instrument. Composer also used more than one compositional technique in his composition. We face many types of these tools such as Serialism and Indeterminacy. Between bars 134 and 159, where the inner trouble is exposed, we find indeterminacy as a primary compositional tool. Composer aimed to achieve the effect of raindrops from single note randomness, thunder effect from a nail glissando while giving freedom to performers to interpret the section in right mood. According to the sound recording of the performance, the section reaches its goal. While imitating the natural phenomena like rain, storm, thunder, heartbeats, composer tries to find out the dramatic side of the piece. According to findings, unisons (ex. $1^{\text {st }}-8^{\text {th }}$ bars), rubato chords (ex. $9^{\text {th }}, 23-24^{\text {th }}$ bars), the sections that include octave appreciation (ex. 22 $2^{\text {nd }}, 26-27^{\text {th }}$ bars), tremolos (ex. $13^{\text {th }}, 43-69^{\text {th }}$ bars), the passages that include fastness of some chromatic six-tuplets (ex. $78-82^{\text {nd }}$ ), staccato passages, legato passages and many passages that include pedal techniques are found besides many extended techniques such as pressing the keys without producing any sound in order to sustain the harmonics of the chords, randomized cluster chords, nail glissando and many more.

According to the analysis done, the piece has very important role in Turkish piano literature as a modern composition for 6-hands that bears educational qualities. Considering the limited amount of research done in this field (Deniz, 2015, Akbulut Demirci 2016) this musical example can be recommended to the scholars in music schools, conservatories and professional music institutions to be thought.

\section{REFERENCES}

Akbulut Demirci, S. (2016). Six Hands Piano in Turkey, 7th ICEEPSY 2016 International Conference on Education \& Educational Psychology 11-15 October 2016, Rhodes - Greece Abstract Book p.22.

Bach, Johann Christoph Friedrich (n.d.). Sonata A Major Four Hands, Wilhelmshaven: Edition Pegasus.

Beethoven, Ludwig van (1993). Complete Works for Piano Four Hands, Vienna: Wiener Urtex Edition, Schott/ Universal Edition.

Beyer, Ferdinand (n.d.). Preparatory School Op.101, Sofia: Musikverlag Lyra Publishing. 
Brahms, Johannes (2004). Serenade Nr.2 A-dur for Piano Four Hand Op.16, Kassel, Basel, London, New York, Prag: Barenreiter Urtex.

Debussy, Claude (n.d.). Small Suit for Four Hands Piano, Paris: Durand\&C.

Debussy, Claude (1991). Works for Piano Four Hands and Two Pianos, New York: Dover Publications, Inc.

Deniz, J. (2015). The Effectiveness of Cooperative Learning Method on Teaching Six Hands Piano Pieces: An Action Research, The Journal of academic and Social Science, 3, 15.

Ereren, Deniz, (2009). Easy Piano. Istanbul: Alfa Publishing.

Godard, Benjamin (n.d.). Waltz Chromatic Op. 88. Paris: Heugel\&C.

Gregh, Louis (n.d.). The Merry Butterflies, Paris: A. Rouart, Lerolle \&C.

Gurlitt, Cornelius (n.d.), (2003). Six Pieces for Six Hands, California: Neil A. Kjos Music Company.

Hasan Barlş Gemici's Short Bio, personal communication, $3^{\text {rd }}$ November 2017.

Illyasoğlu, Evin (1996), Music over Time, Istanbul: Yapı Kredi Publishing.

Moszkowski, Moritz (n.d.). Spanish Dances Op.12 Piano Duet, London, Frankfurt/m., Leipzig, New York: Edition Peters.

Kütahyal, Önder (1981), Contemporary Music History, Ankara: Publisher Nejat Illhan Leblebicioğlu.

Program note of "SKY", personal communication, $3^{\text {rd }}$ November 2017.

Rare Six Hands Piano, 10.01.2010. Retrieved from http://www.wikizero.net/index.php? $q=a H R O c H M 6 L y 9 l b i 53 a W t p c G V k a W E u b 3 J n L 3 d p a 2 k v U G l$ hbm9fc2l4X2hhbmRz.

Say, Ahmet (2010). Music Encyclopedia, Ankara: Music Encyclopedia Publishing.

Six Hands Piano Concert News, Anayurdu Newspaper, 1 st October 2016, http://www.anayurtgazetesi.com/haber/Alti-el-piyano-TSKM-de/541214

Six Hands Piano Concert News, 1st October 2016, http://www.kulturmafyasi.com/oda-muzigiucuncu-kez-sehre-geliyor/

Six Hands Piano Concert News, Andante News, 1st October 2016, https://www.andante.com.tr/tr/4193/3.-istanbul-Uluslararasi-Opus-Amadeus-Oda-Muzigi-

Festivali-2-Mart-\%E2\%80\%93-11-Nisan-2014

Six Hands Piano Concert News, Istanbul Agency, 1st October 2016, http://www.istanbulajansi.ist/haber/opus-amadeus-oda-muzigi-besiktasta/11033 .

Six Hands Piano Concert News, 1st October 2016, http://evetbenim.com/2-mart-11-nisan-iiiistanbul-uluslararasi-opus-amadeus-oda-muzigi-festivalil.

Six Hands Piano Concert News, 1st October 2016, http://www.salom.com.tr/haber-94785opus_amadeusta_gong_caldi.html .

Straus, N. Joseph, (1999). Introduction to Post-Tonal Theory. New Jersey: Pearson Prentice Hall. The Tomb of Schnittke's Photo, 17.01.2017. Retrieved from https://images.search.yahoo.com/search/images;_ylt=AwrJ7JPvzFlapHUA3UJXNyoA;_ylu=X 3oDMTEyZ3Z1b2hvBGNvbG8DYmYxBHBvcwMxBHZOaWQDVUkyQzNfMQRzZWMDc2M-

$? p=$ the + tomb + of + schnittke $\& f r=$ spigot - chr -

ffmac\#id=5\&iurl=http\%3A\%2F\%2Fmedia. gettyimages.com\%2Fphotos\%2Fthe-grave-ofsoviet-and-german-composer-alfred-schnittke-in-cemetery-picture-

id144700349\%3Fs\%3D612x612\&action=click

TRT Radio Recording of the "SKY", $1^{\text {st }}$ October 2016, http://radyo.trt.net.tr/podCast.aspx?OID=8d119fc0-a055-49d8a276f44accbf $8 f$

40\&OIDIslem =18115034-2f79-4f50-9707-e792310cef40 .

Ünaldl, Özgür, (2017). Özgür Ünaldı's Concerts, Retrieved From http://www.ozgurunaldi.com/tr/Konserler/, 18 January 2017.

Research Article - This article was checked by Turnitin

Copyright (C) The Turkish Online Journal of Design, Art and Communication 